\title{
ATRAVÉS DAS CENAS: PORNOGRAFIA E VIOLÊNCIA CONTRA AS MULHERES
}

\section{ARTIGO DE REVISÃO}

SCORSATTO, Andressa dos Santos ${ }^{1}$, LANGARO, Flávia Nedeff ${ }^{2}$

SCORSATTO, Andressa dos Santos. LANGARO, Flávia Nedeff. Através das cenas: pornografia e violência contra as mulheres. Revista Científica Multidisciplinar Núcleo do Conhecimento. Ano. 07, Ed. 01, Vol. 04, pp. 48-88. Janeiro de 2022. ISSN: 2448-0959, Link de acesso: https://www.nucleodoconhecimento.com.br/psicologia/pornografia-e-violencia, DOI: 10.32749/nucleodoconhecimento.com.br/psicologia/pornografia-e-violencia

\section{RESUMO}

A pornografia inegavelmente tornou-se parte da cultura ocidental, constituindo narrativas que dissertam sobre a forma como os sujeitos são encarados no imaginário social, inclusive no tocante às relações entre homens e mulheres. Considerando que tais relações são marcadas pela dominação masculina, que frequentemente naturaliza a violência contra a mulher, o presente estudo partiu da seguinte pergunta norteadora: como a pornografia mainstream reverbera a violência contra as mulheres e quais suas consequências psicológicas nesse grupo? Para tanto, realizou-se uma pesquisa bibliográfica a fim de retomar determinados momentos históricos e sociais que ilustram como a violência contra a mulher foi instituída, tornando-se legítima, e a influência das diferenças de gênero na manutenção da relação de poder dos homens sobre as mulheres, vinculando as informações obtidas à psicanálise. Sendo assim, esta pesquisa objetiva compreender de que forma a pornografia mainstream reflete a violência contra as mulheres e quais os possíveis impactos psicológicos nas mulheres

\footnotetext{
${ }^{1}$ Graduada em Psicologia no Instituto de Filosofia e Ciências Humanas da Universidade de Passo Fundo. ORCID: 0000-0002-2458-7884.

${ }^{2}$ Orientador. ORCID: 0000-0002-4476-6177.
}

RC: 105148

Disponível em: https://www.nucleodoconhecimento.com.br/psicologia/pornografia-eviolencia 
em decorrência desse discurso. Os dados sugerem que a pornografia retrata a violência contra a mulher, tão recorrente através da história, com a finalidade de promover excitação sexual. Isso se deve, em partes, porque a pornografia mainstream é produzida a partir da óptica patriarcal, revelando as percepções inconscientes que a cultura tem a respeito do papel da mulher. No entanto, para além de um simples reflexo da subjetividade dos sujeitos, a narrativa produzida pela pornografia contribui para a legitimação da violência conta as mulheres, gerando impactos psicológicos relativos à propagação de um discurso de ódio, na medida em que promove o silenciamento e a manutenção destas engrenagens. Outrossim, as produções impõem estereótipos e comportamentos geradores de sofrimento, funcionando como uma nova forma de opressão sobre as mulheres.

Palavras-chave: a mulher na sociedade, violência contra a mulher, pornografia.

\section{INTRODUÇÃO}

Recentemente tornou-se notável que discussões referentes ao papel da mulher na sociedade, à violência contra a mulher, à objetificação do corpo feminino, entre outros tópicos que dizem respeito às dinâmicas entre homens e mulheres, têm crescido $\mathrm{e}$ consolidado uma pauta cada vez mais urgente. A realidade é que a relação de dominação dos homens sobre as mulheres mostra desfechos lamentáveis, conforme evidencia uma matéria da CNN (2021), apontando que ao menos 5 mulheres foram assassinadas ou vítimas de violência por dia, no ano de 2020, somando registros de São Paulo, Rio de Janeiro, Bahia, Ceará e Pernambuco. Embora as violências enfrentadas pelas mulheres sejam claras em inúmeras esferas, algumas são muito sutis, porém mostram-se potencialmente danosas.

As raízes da violência contra a mulher remetem a um passado remoto, tendo como base uma sociedade misógina e patriarcal, com todas as implicações que estas qualificações são capazes de conter. A cristalização destes aspectos no imaginário coletivo é perceptível, mostrando-se na reprodução de um pensar e agir frente ao ser mulher que atravessa o inconsciente dos sujeitos, como uma herança destrutiva. As 
formas de violência resultantes dessas percepções podem ser mais ou menos veladas e mascaradas nos dias de hoje, mas seguem existindo, inclusive na pornografia. Assim, a discussão acerca da pornografia insere-se nesse contexto mostrando-se extremamente complexa, pois além do conteúdo produzir diferentes efeitos nos sujeitos, indiscutivelmente tornou-se parte da cultura ocidental. Diante do exposto, indaga-se: de que modo a pornografia mainstream é capaz de refletir a violência contra as mulheres e qual o seu impacto psicológico nesses sujeitos? Tendo como objetivo compreender de que forma a pornografia mainstream reflete a violência contra as mulheres e quais os possíveis impactos psicológicos nas mulheres em decorrência desse discurso

Embora a pornografia possa afetar ambos os gêneros, na medida em que cria padrões e estereótipos a serem seguidos, Ribeiro (2016) afirma que afeta demasiadamente mais as mulheres, visto que naturaliza violências e reproduz misoginia. Sendo assim, o presente estudo objetivou compreender de que maneira a pornografia mainstream reflete a violência contra a mulher e quais os possíveis impactos psicológicos nas mulheres em decorrência dessa violência. Para tanto, realizou-se uma revisão bibliográfica que buscou explicar os fenômenos históricos e sociais que alicerçam tal cenário de violência, bem como compreender de que forma a violência contra a mulher torna-se legítima - sendo transmitida entre as gerações - e como as diferenças entre os gêneros podem contribuir para manutenção das relações de poder, articulando os dados coletados a saberes psicanalíticos.

\section{REFERENCIAL TEÓRICO}

\subsection{HISTÓRIA DA MULHER NA SOCIEDADE}

Objetivando aprofundar a compreensão sobre os fenômenos que permeiam a violência contra a mulher, deve-se analisar não apenas os contextos atuais e individuais que envolvem essa problemática, mas fatos históricos e sociais que escoram esses fenômenos nos dias de hoje. A história é base para a compreensão dos fatores que o presente estudo almeja esmiuçar, tendo em vista que as causas

RC: 105148

Disponível em: https://www.nucleodoconhecimento.com.br/psicologia/pornografia-eviolencia 
sociais e psicológicas que configuram um cenário de violência contra a mulher são consequências de circunstâncias históricas, presentes no cenário social. Conforme aponta a análise freudiana: "Na vida psíquica do indivíduo, o outro é, via de regra, considerado como modelo, como objeto e como adversário, e por isso a psicologia individual é também, de início, simultaneamente psicologia social [...]" (FREUD, 1921, p. 137). Portanto, ainda que seja possível tratar de forma supérflua um conteúdo repleto de complexidades, é preciso resgatar, mesmo que brevemente, alguns recortes relacionados à história das mulheres no presente trabalho.

Se hoje os cuidados maternos são essenciais para a sobrevivência humana, nos períodos que antecederam a criação de instituições na sociedade civilizada o papel da mãe representava o poder de vida e morte. De acordo com Lerner (1986), era imprescindível que as mulheres dedicassem sua vida para ter filhos e criá-los, aspirando a sobrevivência do grupo, que era do interesse de todos. Assim sendo, a primeira divisão sexual do trabalho possivelmente ocorreu devido às diferenças biológicas entre os sexos, em que as mulheres optaram por ocupações compatíveis com a função materna. No entanto, este dado não quer dizer que a divisão sexual do trabalho ocorrida depois, alicerçada na maternidade, tenha surgido por motivos biológicos/naturais. De fato, "[...] a dominância masculina é um fenômeno histórico porque surgiu de um fato biologicamente determinado e tornou-se uma estrutura criada e reforçada em termos culturais ao longo do tempo" (LERNER, 1986, p. 11). Em outros termos, as inevitáveis diferenças biológicas entre homens e mulheres serviriam de pretexto para demarcar discrepâncias construídas posteriormente.

Beauvoir (1949) expõe que, quando a espécie humana se fixa ao solo e torna-se agricultora, a mulher assume grande importância, que pode ser explicada devido ao valor que a criança assume no contexto de trabalhadores que exploram o solo apropriar-se do solo, sob a forma de uma propriedade coletiva, implica a necessidade de uma posteridade e, nesse cenário, a maternidade torna-se uma função sagrada. Em contraponto às tribos nômades que se viam presas ao instante, as comunidades agrícolas veneravam antepassados totêmicos e interessavam-se por seus descendentes, reconhecendo seus filhos como seus. Muitos povos sequer conheciam

RC: 105148

Disponível em: https://www.nucleodoconhecimento.com.br/psicologia/pornografia-eviolencia 
ou atribuíam importância ao pai na concepção, enquanto a mãe era inegavelmente necessária. Era na mulher que o clã se propagava e, por isso, frequentemente era ao clã da mãe que os filhos pertenciam, através delas que a propriedade era transmitida e, misticamente, a terra pertencia às mulheres. "A natureza na sua totalidade apresenta-se [...] como uma mãe; a terra é mulher, e a mulher é habitada pelas mesmas forças obscuras que habitam a terra" (BEAUVOIR, 1949, p. 103).

A concepção de que a inferioridade feminina e a dominação masculina é natural pode ser justificada por uma parcela dos sujeitos que consideram que à mulher foi atribuída, devido a fatores divinos, uma função biológica diferente e inferior e que, por essa razão, a ela necessariamente devem ser designadas diferentes tarefas sociais. No século XIX, quando a importância da explicação religiosa foi minimizada, a ciência buscou explicar a inferioridade feminina, entendendo que sua constituição biológica não condizia com certas atividades. O pensamento predominante do homem-caçador que deve proteger a mulher vulnerável, destinada à maternidade, mostra-se contraditório nos dias de hoje, visto que, ao passo que aceita as mudanças culturais e progressos que libertaram os homens da natureza, condena as mulheres a permanecerem restritas à sua biologia (LERNER, 1986).

Além do pensamento do homem-caçador que precisa proteger as mulheres e crianças do seu grupo ser inaplicável à atualidade, hoje há evidências de que, em grande parte das sociedades de caçadores-coletores, a caça de grandes animais era secundária, sendo que os principais alimentos eram provenientes de atividades exercidas por crianças e mulheres (LERNER, 1986). Embora homens e mulheres tivessem papéis distintos, eram vistos como complementares e igualmente necessários. O mito do homem-caçador, portanto, visa sustentar a supremacia masculina (BOULDING, 1983 apud LERNER, 1986).

O progresso da agricultura durante o Período Neolítico estimulou o fenômeno da troca de mulheres entre as tribos, em que as mulheres eram trocadas ou compradas, como meio de evitar conflitos e gerar mais filhos, futuros trabalhadores. Assim, sua sexualidade e capacidade reprodutiva eram transformadas em "coisas". Entretanto, 
elas ainda mantinham certo poder e liberdade, mesmo que em menor proporção que os homens, como na atualidade. Porém, "[...] uma vez que sua sexualidade, um aspecto de seu corpo, era controlado por outros, as mulheres não apenas estavam em desvantagem, como também restritas de maneira muito particular em termos psicológicos" (LERNER, 1986, p. 263). Ademais, em conflitos intertribais, as mulheres foram as primeiras a serem escravizadas, sendo a sua sexualidade usada como mão de obra e seus filhos como propriedade. Posteriormente, na Mesopotâmia, mulheres pobres eram vendidas por suas famílias para a prostituição ou casamentos. Na Antiga Mesopotâmia, assim como na Antiguidade Clássica e em sociedades escravocratas, os filhos das mulheres também eram adquiridos (LERNER, 1986).

"Assim, o triunfo do patriarcado não foi nem um acaso nem o resultado de uma revolução violenta" (BEAUVOIR, 1949, p. 112), mas, sim, foi um processo que iniciou com a humanidade, a partir de um "privilégio" biológico que nunca foi abdicado. Posteriormente, o homem seguiu não reconhecendo a mulher como um semelhante, não a entendendo como um trabalhador igual a ele. Ao tornar-se proprietário do solo, o homem tornou-se também proprietário da mulher e dos filhos, pois necessitava de herdeiros a fim de prolongar a sua própria vida. A partir da criação da propriedade privada constrói-se a noção de herdeiro, para saber quem receberá a terra (BEAUVOIR, 1949).

A condição da mulher cristalizou-se com a noção de propriedade privada. Os homens, ao compreenderem o seu papel na concepção de um filho, percebem a necessidade de que as relações se tornem monogâmicas, para que fosse possível saber quem seria o seu herdeiro (PEDRO; GUEDES, 2010). Assim, a sociedade passa a denominar-se patriarcado: "Nesta sociedade patriarcal, alicerçada na propriedade privada, a família e a superioridade masculina, além da natureza feminina que possibilita a reprodução, transformam as mulheres em elementos de exploração e opressão" (GRISCI, 1994 apud PEDRO; GUEDES, 2010). O órgão sexual irá determinar as funções sociais dos membros da sociedade. As atribuições designadas aos homens ou as mulheres, portanto, não devem ser consideradas naturais ou biológicas, mas construídas. Sendo assim, se o patriarcado começou em um ponto da RC: 105148

Disponível em: https://www.nucleodoconhecimento.com.br/psicologia/pornografia-eviolencia 
história, não deve ser considerado natural, mesmo que a cultura se proponha a naturalizá-lo. Destaca-se a família na manutenção dessa ordem que, além de educar os filhos para segui-la, reforça seus valores e regras (LERNER, 1986).

Se antes a opressão da mulher existia, porém não havia instituições que legitimavam as desigualdades, uma vez que o patriarcado se encontrava estabelecido esse cenário foi modificado, considerando que os homens passaram a compor os códigos de modo geral, como as mitologias (BEAUVOIR, 1949). Os mitos das deusas da fertilidade e da Deusa-Mãe constam no Período Neolítico. Possivelmente, a adoração a essas divindades decorreu da ligação psicológica entre mãe e filhos. Conforme supracitado, e também demonstrado por Freud (1930 apud LERNER, 1986), a mãe/ambiente favorece uma interação que será responsável por humanizar. A dependência do bebê é extrema e a mãe mostra-se uma figura poderosa, tendo controle sobre o destino da criança. Os homens e mulheres, então, adoravam-na. As deusas demoraram a ser rebaixadas, mesmo após a subordinação das mulheres durante o patriarcado. Porém, o posterior destronamento delas por um único deus masculino constituiu uma desvalorização simbólica das mulheres na sociedade ocidental (LERNER, 1986).

Os mitos são fontes importantes para a compreensão do imaginário de um determinado povo. Holland (2010 apud MOTERANI; CARVALHO, 2016), tentando traçar o momento em que a misoginia foi institucionalizada, afirma que sua origem possivelmente corresponde ao século VIII a.C., no Mediterrâneo Oriental. A saber, misoginia, de acordo com o dicionário Houaiss et al. (2004 apud MOTERANI; CARVALHO, 2016, p. 168), é definida como "ódio ou aversão às mulheres, aversão ao contato sexual"; segundo o dicionário Online Michaelis (2020), consiste em "antipatia ou aversão mórbida às mulheres"; para o Cambridge Dictionary Online (2015 apud MOTERANI; CARVALHO, 2016, p. 168), seria a "[...] crença de que os homens são muito melhores que as mulheres". A misoginia pode ser expressa de diferentes maneiras, "incluindo a discriminação sexual, denegrição das mulheres, violência e objetificação sexual das mulheres" (MOTERANI; CARVALHO, 2016, p. 168).

RC: 105148

Disponível em: https://www.nucleodoconhecimento.com.br/psicologia/pornografia-eviolencia 
Holland (2010 apud MOTERANI; CARVALHO, 2016) afirma que, durante o século VIII a.C., elaboraram-se histórias referentes à criação, na Grécia e Judeia, que narravam a queda do homem devido à mulher, apresentada como responsável por todo o sofrimento humano. A Grécia, considerada por muitos o berço da civilização ocidental, criou o mito da Pandora - a primeira mulher criada por Zeus para vingar-se de Prometeu, personagem provida de beleza e maldade. Portando um cântaro, presente dos deuses, que continha todos os males e enfermidades do mundo, Pandora demonstra que, apesar de bela, abrigava um mal interior. Como a raça das mulheres expandiu-se a partir de Pandora, as mulheres carregam o seu demérito (SCHOTT, 1996 apud MOTERANI; CARVALHO, 2016).

O Orfismo, religião grega que cultua o deus Dionísio, também influenciou na percepção da mulher como responsável pela desgraça do mundo (SCHOTT, 1996 apud MOTERANI; CARVALHO, 2016). O Cristianismo, influenciado pelo Orfismo, corrobora na retratação misógina da mulher, narrando a expulsão do homem e da mulher do paraíso, pois ela cedeu à tentação de pecar, acarretando para toda a humanidade a perda da noção divina. Assim, como pecadora e em condição de inferioridade, a mulher busca redimir-se, submetendo-se e resignando-se ao homem. O mundo moderno ainda está imbuído de práticas atreladas a estes símbolos, em que a mulher alcançará o perdão exercendo a maternidade, zelando o lar, sendo dócil e submissa, entre outros costumes (BICALHO, 2001 apud MOTERANI; CARVALHO, 2016). "Das virtudes ambivalentes de que ela se revestia retém-se principalmente o aspecto nefasto: de sagrada, ela se torna impura" (BEAUVOIR, 1949, p. 116). Eva condena os humanos; Pandora desencadeia os males do mundo; institui-se que a mulher é o mal e o homem é o bem.

O temor à figura da mulher juntamente com a misoginia, sempre promovidos na cultura cristã, favoreceu o surgimento, na Europa, de uma perseguição direcionada, prioritariamente, às mulheres: a caça às bruxas. De acordo com Federici (2004), em um contexto em que a corrupção do clero se tornou notória, além de todas as problemáticas que envolviam as relações feudais, a heresia popular surgiu como uma tentativa de resistência à economia monetária de criar uma nova sociedade, RC: 105148

Disponível em: https://www.nucleodoconhecimento.com.br/psicologia/pornografia-eviolencia 
denunciando aspectos como as hierarquias sociais, a acumulação de riquezas e a situação das mulheres. Nesse cenário, criou-se "[...] uma das instituições mais perversas jamais conhecidas na história da repressão estatal: a Santa Inquisição" (FEDERICI, 2004, p. 69). Também denominada como Tribunal do Santo Ofício, tinha como propósito combater qualquer movimento que ameaçasse a doutrina católica (SILVA, 2018).

A peste negra, decisiva nas lutas medievais, mudou o contexto do proletariado europeu devido à escassez de mão de obra - resultante da crise demográfica - e consequente reviravolta nas hierarquias sociais. Desse modo, visando a dissolução dos protestos dos trabalhadores, houve a criação de uma política sexual. Uma das medidas consistiu na institucionalização da prostituição na Europa com os bordéis municipais, que eram financiados por impostos. A Igreja, inclusive, encarou a prostituição como uma atividade legítima para prevenir práticas sexuais consideradas hereges, como a homossexualidade, atuando como uma "proteção" para a vida familiar. Ademais, o estupro coletivo tornou-se aceitável e comum, com grupos que invadiam casas ou arrastavam as vítimas sem receio (FEDERICI, 2004). Os efeitos gerados para as mulheres proletárias, que eram as principais atingidas, são imensuráveis, visto que precisavam abandonar suas cidades ou tornarem-se prostitutas, devido à reputação arruinada (RUGGIERO, 1985 apud FEDERICI, 2004). Infelizmente, as consequências foram ainda mais devastadoras para as mulheres em geral:

\footnotetext{
A legalização do estupro criou um clima intensamente misógino que degradou todas as mulheres, qualquer que fosse sua classe. Também insensibilizou a população frente à violência contra as mulheres, preparando o terreno para a caça às bruxas que começaria nesse mesmo período. Os primeiros julgamentos por bruxaria ocorreram no final do século XIV; pela primeira vez, a Inquisição registrou a existência de uma heresia e de uma seita de adoradores do demônio completamente feminina (FEDERICI, 2004, p. 104).
}

Cada vez mais o herege assumia a figura de uma mulher, sendo que "[...] mais de $80 \%$ das pessoas julgadas e executadas na Europa nos séculos XVI e XVII pelo crime de bruxaria eram mulheres" (FEDERICl, 2004, p. 323). A caça às bruxas teve seu ápice entre 1580 e 1630, quando o contexto social era de revoltas populares,

RC: 105148

Disponível em: https://www.nucleodoconhecimento.com.br/psicologia/pornografia-eviolencia 
epidemias e as relações feudais cediam lugar às instituições do capitalismo mercantil. No entanto, a perseguição às bruxas não surgiu espontaneamente. Antes do pânico instaurar-se entre as pessoas, houve o doutrinamento por meio de autoridades que manifestaram publicamente a sua preocupação, contando com propagandas e tornando o tema destaque nos debates entre os intelectuais da época. A caça às bruxas foi um ataque à sexualidade das mulheres, ao controle que tinham sobre a sua reprodução - por meio de abortos e métodos contraceptivos, que passaram a ser perseguidos e distorcidos durante a peste negra - à capacidade que possuíam de curar e como forma de dominar aquelas que estavam contra as relações econômicas vigentes. Em suma, era também um instrumento do patriarcado visando submetê-las ao controle do Estado (FEDERICI, 2004).

De acordo com Federici (2004), o sadismo sexual e a misoginia são evidenciados nas torturas, em que as mulheres eram depiladas, furadas com agulhas (inclusive na vagina), estupradas, poderiam ter seus membros arrancados, ossos esmagados, serem enforcadas ou queimadas em eventos públicos. Os homens passaram a temer as mulheres à sua volta e muitos consideravam-se caçadores de bruxas ou aproveitaram as circunstâncias para livrarem-se das mulheres indesejadas. Assim, a atividade sexual feminina passou a ser vista como algo demoníaco, pervertida por natureza e que deveria favorecer unicamente os homens e a procriação. Inclusive, "[...] a produção da 'mulher pervertida' foi o primeiro passo na transformação da sexualidade feminina em trabalho" (FEDERICl, 2004, p. 345). Nessas circunstâncias que os ideais de feminilidade e domesticidade começaram a ser construídos sobre as mulheres. A caça às bruxas foi levada inclusive para a América, sobre o pretexto de que o demônio foi expulso da Europa para outros territórios (SILVA, 2018), justificando a colonização e o tráfico de escravos. Dessa maneira, enquadrar a negritude e a feminilidade como sinais de bestialidade serviu para naturalizar a exploração desses sujeitos (FEDERICI, 2004).

Ao analisar as diferentes formas de opressão que são impostas às mulheres, destacase a questão do sistema escravagista, que definia seres humanos como uma propriedade. O princípio da escravidão imprimia facetas distintas para mulheres e 
homens escravizados: "[...] os homens eram primeiro explorados como trabalhadores; as mulheres eram sempre exploradas como trabalhadoras, fornecedoras de serviços sexuais e reprodutoras" (LERNER, 1986, p. 264). Séculos mais tarde, considerando a institucionalização das concepções alusivas às mulheres, a história desemboca na escravidão no continente americano.

Enquanto a feminilidade estava em voga nos Estados Unidos durante o século XIX, em que as mulheres brancas eram cobradas para desempenharem um papel de mães e donas de casa amáveis, a maior parte das escravas trabalhavam em lavouras, juntamente com os homens, coletando algodão, cortando cana e colhendo tabaco. A ideologia da feminilidade, popularizada por meio de revistas e romances dedicados ao público feminino, separou as mulheres brancas do mundo produtivo, instituindo com ainda mais força uma suposta inferioridade feminina. Em contrapartida, entre as escravas esses papéis não poderiam ser incorporados. "As mulheres não eram 'femininas' demais para o trabalho nas minas de carvão e nas fundições de ferro, tampouco para o corte de lenha e a abertura de valas" (DAVIS, 1981, p. 22). O trabalho doméstico, símbolo da inferioridade feminina, além de não ser exclusivamente feminino para a comunidade de escravos, era o único significativo. Outrossim, a exaltação da maternidade, que encerrava grande parte das mulheres ao ambiente doméstico, não se aplicava às escravas. Do ponto de vista dos proprietários, as mulheres escravas não eram mães, mas reprodutoras (DAVIS, 1981).

A produtividade exigida de homens e mulheres escravizados era a mesma, entretanto, no que diz respeito às penalizações, as escravas tinham o agravante de diversas formas de punições sexuais. Enquanto os homens eram açoitados e mutilados, as mulheres eram, também, estupradas. Assim,

A postura dos senhores em relação às escravas era regida pela conveniência: quando era lucrativo explorá-las como se fossem homens, eram vistas como desprovidas de gênero; mas, quando podiam ser exploradas, punidas e reprimidas de modos cabíveis apenas às mulheres, elas eram reduzidas exclusivamente à sua condição de fêmeas (DAVIS, 1981, p. 19). 
O estupro era uma forma de dominar e reprimir as escravas, ao passo que desmoralizava seus companheiros. A função do estupro também pôde ser observada durante a Guerra do Vietnã, em que passou a ser "socialmente aceitável": o comando militar dos Estados Unidos encorajava os soldados a estuprarem as mulheres vietnamitas - destacadas por suas contribuições na luta de libertação do seu povo porque, na visão desses homens, a guerra era uma questão masculina. Analogamente, se as escravas tomassem consciência de sua força e resistência, os abusos sexuais relembrariam a sua condição enquanto fêmeas. Mesmo com o advento da emancipação, os diversos abusos que as mulheres sofriam rotineiramente em seus ambientes de trabalho não foram interrompidos. Como agravante, criou-se um mito referente à "imoralidade" das mulheres negras, que passaram a ser vistas como figuras promíscuas e animalizadas, fato que acirrou ainda mais a rivalidade entre as mulheres (DAVIS, 1981).

A construção da feminilidade foi um importante aspecto que influenciou a subjetivação das mulheres. A Europa, nos séculos XVIII e XIX, construiu discursos filosóficos, médicos e científicos sobre a natureza da mulher, com o propósito de adequá-las a um "[...] conjunto de atributos, funções, predicados e restrições denominado feminilidade" (KEHL, 1998, p. 40, grifo do autor). Para a maioria dos intelectuais desse tempo, a feminilidade seria própria dessa parcela da população devido às particularidades de seus corpos, destinando-as à família, ao espaço doméstico e à maternidade. A feminilidade, portanto, é produzida a partir da posição masculina, sendo uma construção discursiva que a sociedade anseia que as mulheres correspondam. Para performar a feminilidade, eram exigidas algumas virtudes, como "[...] o recato, a docilidade, uma receptividade passiva em relação aos desejos e às necessidades dos homens e, a seguir, dos filhos" (KEHL, 1998, p. 40).

Este movimento dedicado à produção de um ideal ao qual as mulheres deveriam adequar-se indica que havia uma desordem social, uma desestabilização - entre várias que ocorreram no decorrer da história - da relação das mulheres com a feminilidade. 
A enorme produção teórica entre os séculos XVIII e XIX destinada a fixar a mulher no lugar ao qual a sua verdadeira natureza a destinou nos faz desconfiar da "naturalidade" desse lugar. Recordemos a advertência freudiana de que onde não há desejo não é necessário que exista um tabu; ou, com Lacan, que o discurso insiste justamente onde não se encontra a verdade do sujeito (KEHL, 1998, p. 49, grifo do autor).

Kehl (1998) coloca que essa instabilidade iniciou no século XVII e tornou-se perigosa no fim do século XVIII, quando os revolucionários da Revolução Francesa passaram a atribuir sentido público e político inclusive às questões da vida que hoje são do interesse privado. Nesse contexto, motivadas por ideias iluministas, as mulheres brancas foram às ruas, tornando-se protagonistas em manifestações públicas. Mais tarde, na Inglaterra e Alemanha, as mulheres passaram a contestar a submissão ao casamento e à maternidade. Poucos homens, inclusive entre intelectuais e revolucionários, aceitaram o iminente abandono da vida doméstica por parte das mulheres. Segundo Kehl (1998), o pensamento iluminista, que valoriza aspectos como a supremacia da razão e a emancipação do indivíduo, influenciou de modo indireto as primeiras ideias feministas na Europa.

De acordo com Pedro e Guedes (2010), o movimento feminista, iniciado na década de 60 nos Estados Unidos e Europa, teve um importante papel na luta das mulheres em busca da liberdade - não apenas almejando igualdade econômica e política em relação aos homens, mas visando marcar que as mulheres são sujeitos autônomos, livres. Um grande símbolo do movimento foi quando mulheres do Women's Liberation Movement planejavam pôr fogo nos objetos que representam a ditadura da beleza, como sutiãs e espartilhos, trazendo à tona a discussão sobre as questões de gênero. As autoras afirmam que, na sociedade brasileira, o movimento feminista possuiu suas peculiaridades, considerando o patriarcalismo e conservadorismo do país. Na década de 60, organizações femininas começaram a agrupar-se no território brasileiro, em busca de espaço no mercado de trabalho e igualdade. Com o golpe de 1964, o movimento das mulheres passou a ser reprimido pela ditadura, contando, entretanto, com importante resistência.

RC: 105148

Disponível em: https://www.nucleodoconhecimento.com.br/psicologia/pornografia-eviolencia 
A Lei Maria da Penha, sancionada em 2006, foi uma grande conquista do movimento feminista do Brasil, que pôde esclarecer as diversas formas de violência que as mulheres poderiam ser vítimas, tendo em vista que uma pesquisa de 2001, da Fundação Perseu Abramo, constatou que 43\% das mulheres já sofreram alguma violência (PEDRO; GUEDES, 2010). De acordo com o site do Ministério Público de São Paulo, a Maria da Penha, que inspirou o nome da lei, foi uma brasileira vítima de duas tentativas de assassinato por parte do seu marido, ficando paraplégica. Embora a sociedade como um todo tenha passado por importantes transformações no que tange à condição da mulher, ainda há resquícios de uma cultura violenta, que naturaliza o poder dos homens sobre as mulheres, reforçada por instituições que ancoram a sociedade - dentre elas a família, os mitos e, até mesmo, parte da ciência.

\subsection{A VIOLÊNCIA CONTRA A MULHER}

Conforme a Convenção Interamericana para Prevenir, Punir e Erradicar a Violência Contra a Mulher (1994), violência contra a mulher é "qualquer ação ou conduta, baseada no gênero, que cause morte, dano ou sofrimento físico, sexual ou psicológico à mulher, tanto no âmbito público como no privado". Para além dessa definição, a Lei Maria da Penha (Lei 11.340/2006), em seu Art $7^{\circ}$, define:

I - a violência física, entendida como qualquer conduta que ofenda sua integridade ou saúde corporal;

II - a violência psicológica, entendida como qualquer conduta que lhe cause dano emocional e diminuição da autoestima ou que lhe prejudique e perturbe 0 pleno desenvolvimento ou que vise degradar ou controlar suas ações, comportamentos, crenças e decisões, mediante ameaça, constrangimento, humilhação, manipulação, isolamento, vigilância constante, perseguição contumaz, insulto, chantagem, violação de sua intimidade, ridicularização, exploração e limitação do direito de ir e vir ou qualquer outro meio que the cause prejuízo à saúde psicológica e à autodeterminação;

III - a violência sexual, entendida como qualquer conduta que a constranja a presenciar, a manter ou a participar de relação sexual não desejada, mediante intimidação, ameaça, coação ou uso da força; que a induza a comercializar ou a utilizar, de qualquer modo, a sua sexualidade, que a impeça de usar qualquer método contraceptivo ou que a force ao matrimônio, à gravidez, ao aborto ou à prostituição, mediante coação, chantagem, suborno ou manipulação; ou que limite ou anule o exercício de seus direitos sexuais e reprodutivos;

RC: 105148

Disponível em: https://www.nucleodoconhecimento.com.br/psicologia/pornografia-eviolencia 
IV - a violência patrimonial, entendida como qualquer conduta que configure retenção, subtração, destruição parcial ou total de seus objetos, instrumentos de trabalho, documentos pessoais, bens, valores e direitos ou recursos econômicos, incluindo os destinados a satisfazer suas necessidades;

$\mathrm{V}$ - a violência moral, entendida como qualquer conduta que configure calúnia, difamação ou injúria.

A violência contra a mulher ainda constitui uma triste realidade no Brasil e no mundo. Um exemplo claro é a necessidade da Lei do Feminicídio (lei oㅜ 13.104, de 9 de março de 2015), que diz respeito ao assassinato de uma mulher por ela ser mulher, ou seja, motivado pelo menosprezo ou ódio às mulheres. Segundo relatório da Organização das Nações Unidas (2016), o Brasil tem a quinta maior taxa de feminicídios do mundo. Dito isto, é preciso considerar que, antes de acontecer o feminicídio, a mulher possivelmente foi vítima de outras formas de violência. O mesmo cenário repete-se ao redor do globo: uma reportagem do Portal G1 (2021) aponta que, segundo a Organização Mundial da Saúde, 1 em cada 3 mulheres sofre violência física ou sexual ao longo da vida, sendo o parceiro íntimo o principal agressor.

As relações patriarcais constituem o cerne da violência dos homens contra as mulheres. Tais relações desenrolam-se a partir do poder exercido pela parte dominante sobre a parte dominada, por meio de ameaças, concretizadas ou não, de que punições podem ser empregadas caso essa hierarquia seja desafiada. Com o advento do capitalismo, os homens perderam parte do poder que exerciam sobre as mulheres e o seu lugar de impor regras e decidir o destino da família. Assim, a violência masculina no âmbito doméstico tornou-se ainda mais "necessária", a fim de manter a ilusão de que o privilégio masculino permanece intacto e garantir a hierarquia dos papéis sexuais (HOOKS, 1984). O patriarcado, como outros eventos sociais, mostra-se altamente adaptável. "Se, na Roma antiga, o patriarca detinha poder de vida e morte sobre sua esposa e seus filhos, hoje tal poder não mais existe, no plano de jure. Entretanto, homens continuam matando suas parceiras" (SAFFIOTI, 2004, p. 48 , grifo do autor).

De acordo com Bourdieu (1998), os sujeitos incorporam as estruturas da ordem masculina, tornando-as percepções inconscientes. A divisão entre os sexos, nesse

RC: 105148

Disponível em: https://www.nucleodoconhecimento.com.br/psicologia/pornografia-eviolencia 
contexto, parece ser assimilada como tão natural a ponto de ser inevitável, fazendose presente em todo o mundo social. A força da ordem masculina evidencia-se nesse fato, negando justificativas para a sua primordialidade: "[...] a visão androcêntrica impõe-se como neutra e não tem necessidade de se encaixar em discursos que visem legitimá-la" (BOURDIEU, 1998, p. 18). Em outros termos, a visão androcêntrica do mundo é naturalizada a ponto de dispensar razões para ser, sendo que a própria ordem social cumpre a função de ratificar a dominação masculina onde construiu suas bases, desde a divisão do trabalho, os espaços que reservam ao homem o lugar de assembleia ou mercado, em oposição à mulher, restrita à casa. A realidade biológica do corpo, que difere homens e mulheres, pode ser interpretada como a justificativa natural das diferenças entre os gêneros e da divisão do trabalho (BOURDIEU, 1998).

Em consonância com o supracitado, os sujeitos introjetam os instrumentos criados socialmente para controlar e regulamentar a vida social, e estas atitudes serão transmitidas entre as gerações sem questionamentos (CHAUÍ, 1997 apud MOTERANI; CARVALHO, 2016). As transmissões entre as gerações de um mundo tal como é dado leva à cristalização das ideias. Assim, dissemina-se no imaginário social crenças sobre o mundo que são capazes de tornar legítimas inclusive a violência sexual e física. Bourdieu (1998) denomina de "paradoxo da dóxa" o fato de que a ordem do mundo seja respeitada sem que haja transgressões, subversões e "loucuras":

[...] a ordem estabelecida, com suas relações de dominação, seus direitos e suas imunidades, seus privilégios e suas injustiças, salvo uns poucos acidentes históricos, perpetue-se apesar de tudo tão facilmente, e que condições de existência das mais intoleráveis possam permanentemente ser vistas como aceitáveis ou até mesmo como naturais (BOURDIEU, 1998, p. 11).

A dominação masculina, no contexto descrito, exemplifica esta submissão, resultando da denominada "violência simbólica, violência suave, insensível, invisível a suas próprias vítimas, que se exerce essencialmente pelas vias puramente simbólicas da comunicação e do conhecimento [...]" (BOURDIEU, 1998, p. 12) ou, ainda, do desconhecimento e do sentimento. A lógica para a qual opera a dominação é exercida em prol de algum princípio simbólico que é reconhecido por dominador e dominado, 
mas que prende os sujeitos a uma relação de profunda familiaridade a estas tradições, confundindo as causas e efeitos e induzindo a perceber uma construção social como natural (BOURDIEU, 1998).

Para compreender de que forma a dominação masculina é validada e transmitida de modo invisível e inquestionável entre os seres humanos através da cultura aprovando, inclusive, as mais diversas formas de violência - é essencial resgatar a constituição do sujeito a partir do encontro com o outro. Segundo Freud (1930), para poder viver em sociedade o sujeito precisa assujeitar-se à civilização, renunciando às suas pulsões e reprimindo seus desejos inconscientes, com a finalidade de protegerse da ameaça da natureza e regulamentar o vínculo entre todos. Um dos traços úteis para classificar a civilização é a forma como as relações entre os humanos são balizadas, tornando a maioria do grupo mais influente do que um único sujeito. Devido à evolução cultural, a liberdade individual foi cerceada em uma espécie de troca: renuncia-se à satisfação pulsional almejando uma vida mais segura, com os semelhantes. "Por meio de tabus, leis e costumes, são produzidas mais restrições, que atingem tanto os homens como as mulheres" (FREUD, 1930, p. 67). Tais restrições irão resultar em neuroses, como forma que o psiquismo encontra de lidar com este embate instaurado no sujeito.

Conforme o exposto, a civilização recorre a certos mecanismos para conter os desejos inconscientes - principalmente a agressividade inerente aos humanos - a fim de impedir a sua desintegração e garantir que o ser humano possa conviver com o outro. A nível individual, inicialmente o Eu renuncia à satisfação de suas pulsões devido ao medo da autoridade externa, que equivaleria à perda do amor e, consequentemente, à perda da proteção. Posteriormente, ao estabelecer-se a autoridade interna, a renúncia não é o bastante, haja vista que o desejo não pode ser escondido do Supereu. Assim, troca-se o medo da autoridade externa pela culpa. A civilização também forma um Super-eu, baseado nos registros de personalidades anteriores e instituindo exigências ideais. Nesse ponto, a evolução cultural e individual encontra-se entrelaçadas, em que exigências do Super-eu cultural mostram-se coincidentes com aquelas provenientes do individual (FREUD, 1930).

RC: 105148

Disponível em: https://www.nucleodoconhecimento.com.br/psicologia/pornografia-eviolencia 
Dessa forma, ao nascer o sujeito precisa adequar-se a um contexto que já está dado, dividindo-se entre o seu pulsional e a cultura, sendo o recalque a maneira encontrada para mediar este conflito e garantir a vida em sociedade. Cada sujeito irá estabelecer um laço social diante de personagens que ocupam espaços pré-determinados. Para existir esse laço social, é necessário o vínculo de um agente, que domina, e de um outro, dominado, em uma relação assimétrica. Esses lugares pré-determinados são transgeracionais e consideram que os sujeitos não renunciam ao outro, são lugares da cultura, portanto, simbólicos, sustentados nos discursos (QUINET, 1951).

Considerando que o sujeito se adequa a uma posição que existe antes mesmo do seu nascimento, o conceito do Outro enquanto um lugar, um discurso, que postula para o sujeito aspectos que dizem respeito à sua formação e história, mostra-se fundamental.

O grande Outro como discurso do inconsciente é um lugar. É o alhures onde o sujeito é mais pensado do que efetivamente pensa. É a alteridade do eu consciente. É o palco que, ao dormir, se ilumina para receber os personagens e as cenas dos sonhos. É de onde vêm as determinações simbólicas da história do sujeito. É o arquivo dos ditos de todos os outros que foram importantes para o sujeito em sua infância e até mesmo antes de ter nascido (QUINET, 1951, p. 21).

O eu e o outro são indissociáveis, confundem-se, assemelham-se, "[...] o eu é - antes de mais nada - outro" (QUINET, 1951, p. 8). O eu constitui-se através da imagem do outro, em um processo que Freud denominou como narcisismo primário, o correspondente ao estádio do espelho, de Lacan (QUINET, 1951). O narcisismo primário é uma fase intermediária, de passagem do autoerotismo para o amor objetal, em que o Eu será desenvolvido. Diz respeito ao momento em que a criança volta a sua libido para si, antes de poder direcioná-la aos objetos externos. A relação dos pais com a criança origina este estado, em que eles revivem o seu próprio narcisismo, interrompendo suas aquisições culturais que outrora foram impostas, atribuindo à criança qualidades e ocultando todos os defeitos associados a ela, ou seja, elevandoa à condição de Sua Majestade o Bebê (FREUD, 1914). Portanto, para que um sujeito possa constituir-se, é necessário o investimento narcísico que garantirá as ligações essenciais que darão origem ao Eu, processo denominado "narcisismo transvazante" (BLEICHMAR, 1994).

RC: 105148

Disponível em: https://www.nucleodoconhecimento.com.br/psicologia/pornografia-eviolencia 
Posteriormente, o estado de narcisismo do sujeito será gradativamente abandonado em consequência da identificação com as figuras parentais, caracterizando um Eu que passa a submeter-se às exigências provindas do social. Surge uma instância que o Eu utiliza para comparar-se, um ideal ligado ao mundo externo, que o humano buscará adequar-se, fomentando a repressão (FREUD, 1914). Trata-se de "[...] uma instância simbólica (pois é constituída pelos significantes do Outro), entretanto, ela redobra as exigências narcísicas do sujeito" (QUINET, 1951, p. 26), denominada de Ideal do Eu. Tal instância é o resultado da união do narcisismo - idealização do ego - e das identificações com os pais, seus substitutos e demais ideais advindos do coletivo (LAPLANCHE; PONTALIS, 1982). A gênese do Ideal do Eu é impelida pela crítica dos pais, posteriormente pelos educadores, instrutores e outras inúmeras pessoas que adentram a vida do sujeito - o próximo (FREUD, 1914).

De acordo com Moterani e Carvalho (2016), é possível compreender as repetições das ideias e padrões que perpetuam a dominação masculina através do conceito supracitado de Ideal de Eu. Sendo esta uma estrutura mental que surge a partir da introjeção dos modelos parentais e seus substitutos, é referência para o Eu avaliar suas realizações, portanto uma instância crítica e que serve para a auto-observação. O sujeito que não se adequa às expectativas dos outros - que passam a constituir a própria expectativa do sujeito - sentirá o fracasso. Assim, se é disseminado um Ideal de Eu com uma visão de menosprezo às mulheres, é esperado que os agentes sociais irão identificar-se com essa percepção, inclusive as próprias mulheres. Deste modo, para os que tentam romper com o modelo violento, resta o sentimento de culpa, tendo em vista que é uma tentativa de romper com o que é socialmente esperado e, portanto, internamente esperado. O sentimento de culpa, neste ponto, deriva de uma tensão entre o Eu e o Ideal de Eu: "[...] a frustração causada pela distância entre o que não fomos [...] e a imagem criada pelo ideal de ego daquilo que achamos que deveríamos ter sido (atendendo ao modelo social)" (MOTERANI; CARVALHO, 2016, p. 175).

De acordo com Hooks (1984), a violência contra a mulher pode caracterizar um "ciclo da violência", em que os homens que a praticam sentem que podem submeter as mulheres às violências que eles vivenciam no ambiente externo, sem que sofram RC: 105148

Disponível em: https://www.nucleodoconhecimento.com.br/psicologia/pornografia-eviolencia 
retaliações. Como os ideais masculinos encontram-se centrados na máxima de que expressar dor revela a castração simbólica, contrariando a masculinidade, Hooks (1984) acredita que provocar dor torna-se uma alternativa. Sendo assim, verifica-se que o abuso não está restrito à esfera doméstica, mas estende-se às outras formas de opressões que revelam uma cultura que consente que "superiores" controlem "inferiores", uma relação entre dominantes e dominados. A violência acontece através da naturalização destes lugares, em consonância com a percepção psicanalítica de que a cultura estabelece um laço social entre a gente e o outro, que já está posto e com os quais os sujeitos buscarão identificar-se. Paralelamente, a violência dos homens contra as mulheres justifica-se nesses lugares de assimetria:

[...] o patriarcado é entendido como pertencente ao extrato simbólico e, em linguagem psicanalítica, como a estrutura inconsciente que conduz os afetos e distribui valores entre os personagens do cenário social. A posição do patriarca é, portanto, uma posição no campo simbólico, que se transpõe em significantes variáveis nas distintas interações sociais (ALMEIDA, 2004).

A visão de mundo sob a óptica patriarcal inicia no âmbito familiar, em que a violência frequentemente é naturalizada. A opressão sexista, além de ser a base para as outras formas de opressões, é aquela que a maioria das pessoas experimentam, oprimindo ou sendo oprimidas. A família tem protagonismo, em que o seu papel - de acolher, nutrir e promover vínculos - é distorcido, passando a existir como um espaço em que os sujeitos serão educados para naturalizarem formas de opressão. Enquanto o racismo e a opressão de classes costumam ser experienciados fora de casa, grande parte dos sujeitos vivenciam a opressão sexista no bojo da família (HOOKS, 1984). Em face do exposto, quando o ser humano vem ao mundo, o seu lugar está prédeterminado, inclusive aquele que diferencia homens e mulheres e garante a sua assimetria. A família, na sua condição de primeiro grupo que irá introduzir o sujeito à cultura, responderá à demanda de enquadrar o sujeito no espaço que the é designado.

Conforme Hooks (1984), a cultura que legitima a relação de dominação dos homens frente às mulheres reforça o seu discurso, também, nas produções audiovisuais. No que tange à televisão, bem como outras mídias, frequentemente ocorre uma espécie de glamourização da violência contra a mulher, constituindo um clima de erotismo que

RC: 105148

Disponível em: https://www.nucleodoconhecimento.com.br/psicologia/pornografia-eviolencia 
visa o entretenimento. Isto significa que a sociedade de alguma forma recompensa a violência masculina, tornando-a menos impactante e errada. Averígua-se o mesmo cenário em diversos romances populares, que sugerem que a violência masculina deve ser exercida para forçar a subordinação das mulheres, corrigir o seu "atrevimento", transformando-as em seres submissos e "[...] encorajadas tanto a aceitar a ideia de que a violência aumenta e apimenta o prazer sexual quanto a acreditar que a violência é um signo de masculinidade e um gesto de cuidado [...]" (HOOKS, 1984, p. 184). Dessa forma, há o reforço de comportamentos sexistas, assim como a romantização da violência masculina.

A linguagem, que é anterior a cada sujeito, inscreve os indivíduos na ordem simbólica, sendo que "[...] 'homem' e 'mulher' são os primeiros significantes que designam o sujeito assim que chega ao mundo, antes de qualquer possibilidade de escolha, antes que o infans se constitua um sujeito do desejo" (KEHL, 1998, p. 11, grifo do autor). A partir de uma pequena diferença anatômica pertencente ao Real e constatada no nascimento - ou, até mesmo, antes dele - constituem-se distintos papéis sociais para homens e mulheres, diferenciando-os quanto ao gênero (KEHL, 1998). Para Saffioti (2004), o gênero é um sistema hierárquico e desigual dentro da ordem patriarcal, que admite a dominação das mulheres pelos homens. Ademais, diferentes culturas atribuem suas próprias particularidades ao "ser homem" e "ser mulher", comprovando que não é um processo inato, como sugeria-se no passado, e sim referente às relações sociais (SAFFIOTI, 1998 apud PEDRO; GUEDES, 2010). Partindo desse raciocínio, Beauvoir afirmou que

Ninguém nasce mulher: torna-se mulher. Nenhum destino biológico, psíquico, econômico define a forma que a fêmea humana assume no seio da sociedade; é o conjunto da civilização que elabora esse produto intermediário entre o macho e o castrado, que qualificam de feminino. Somente a mediação de outrem pode constituir um indivíduo como um Outro (BEAUVOIR, 1949, v. 2, p. 11, grifo do autor).

Ou seja, a ideia dos lugares que homens e mulheres ocupam está pronta quando a criança nasce e irá definir de que forma ela será socializada, sendo que as identidades masculinas ou femininas podem variar a partir da rigidez de cada sociedade. Portanto, 
mulher ou homem diz respeito à anatomia do corpo, que, juntamente com atributos da cultura, formam o gênero. O gênero pode articular-se à posição do sujeito no discurso, como sujeito ou objeto -correspondente à diferenciação freudiana "ativo", para a posição dita masculina, e "passivo", para a feminina - como também em relação ao desejo de um semelhante. A feminilidade e a masculinidade inserem-se no plano imaginário, formada pelas identificações dos sujeitos aos ideais de gênero de sua cultura e relativa às estratégias de cada indivíduo em relação ao trinômio falo/falta/desejo (KEHL, 1998).

Acreditar-se portador de um falo, por exemplo, e desejar com isto satisfazer e completar aquela cujo corpo parece garantir que a castração está só do lado das mulheres, é uma composição típica da "masculinidade". Já a feminilidade, costuma organizar-se em torno do imaginário da falta; na feminilidade, a mulher não tem o falo; ela se oferece para ser tomada como falo a partir de um lugar de falta absoluta, do qual só o desejo de um homem pode resgatá-la (KEHL, 1998, p. 12).

Entretanto, as imposições da cultura não são, necessariamente, um destino. A partir da travessia edípica cada sujeito identifica-se com padrões e ideias de gênero, porém, essa mesma travessia produz as diferenças entre os indivíduos, respostas singulares que os deslocam para a posição de sujeitos desejantes (KEHL, 1998). Além disso, graças às mudanças sociais e, em grande parte, ao movimento feminista, muitas mulheres não experienciam as mesmas opressões advindas dos homens em todas as relações. Todavia, é preciso destacar que certas instituições criam o cenário que legitima desigualdades entre homens e mulheres, como no caso das leis, mitos, costumes, religiões, arte, família e, até mesmo, áreas do saber, produzindo um emaranhado cultural que enlaça a constituição dos indivíduos.

A violência contra a mulher, portanto, possui procedências históricas que acompanham a humanidade, sendo uma herança transmitida entre as gerações através dos discursos manifestos e latentes. Ao constituir-se, o sujeito entra em cheque com todo esse acervo que está posto e busca encaixar-se no local da cultura que lhe é designado, garantindo o amor do outro. Os lugares que homens e mulheres ocupam já estão demarcados quando a criança nasce, no meio social, que irá exercer sua força no sujeito. Inicialmente, a família tem papel fundamental na montagem

RC: 105148

Disponível em: https://www.nucleodoconhecimento.com.br/psicologia/pornografia-eviolencia 
desse quebra-cabeças, mas logo a função de adequar o sujeito à cultura será também dos educadores, dos pares e, inclusive, das mídias. Quando o sujeito de alguma forma resiste a esse destino, não é apenas uma autoridade externa que exercerá a coerção, como também uma autoridade internalizada, o superego.

\subsection{PORNOGRAFIA E A VIOLÊNCIA CONTRA A MULHER}

A palavra "pornografia" é oriunda dos vocábulos gregos "pornos", que significa prostituta, e "graphô", referente a escrever, gravar. "Pornos" é da mesma família que "porneuô" (ser prostituta, viver da prostituição) e "pernêmi" (vender, exportar), devido ao fato de as prostitutas serem originalmente escravas (BARROS; BARRETO, 2018). Pouco se sabe sobre as origens da pornografia, no entanto acredita-se que é uma expressão artística antiga como as outras, inclusive representada em pinturas da era paleolítica. Adônis von Zschernitz, por exemplo, tem cerca de 7200 anos, sendo considerada a estátua pornográfica mais antiga (CECCARELLI, 2011). De acordo com o Dicionário Michaelis (2021), pornografia significa:

1. Qualquer coisa (arte, literatura etc.) que vise explorar o sexo de maneira vulgar e obscena [...]

2. Tratado acerca da prostituição.

3. Coleção de pinturas ou gravuras obscenas.

4. Caráter obsceno de uma publicação.

5. Atentado ou violação ao pudor, ao recato; devassidão, imoralidade, libertinagem.

Entretanto, não existe um consenso sobre o significado dessa palavra. Para a Enciclopédia Britânica (apud CECCARELLI, 2011), é a "representação do comportamento erótico em livros, quadros, estátuas, filmes, etc., que se destina a provocar excitação sexual". Alguns entendem que "[...] pode ser definida como a personificação do comportamento sexual através de imagens, sejam elas animadas ou estáticas" (RIBEIRO, 2016, p. 18). Outros autores acrescentam a esse conceito características de hierarquias de gênero. Ao redigir textos legais que tutelavam os 
direitos civis de mulheres em situação de violência devido à pornografia, as autoras Dworkin e Mackinnon, referindo-se à grande indústria pornográfica, atribuíram-na o seguinte significado: "subordinação sexual gráfica explícita da mulher através de imagens e/ou palavras" (DWORKIN; MACKINNON, 1989 apud RIBEIRO p. 22, grifo do autor). Entre outras concepções relativas a um termo de difícil definição, Ribeiro descreveu a pornografia da seguinte forma:

[...] exibição gráfica de materiais sexuais, em que haja a subordinação sexual feminina e degradação das mulheres, deflagrada através de comportamentos agressivos, abusivos e degradantes, num contexto de dominação masculina, de maneira que se pareça endossar, encorajar ou normalizar a violência de gênero. Outros elementos, à exemplo da exibição das mulheres como objetos sexuais desumanizados, podem ser acrescidos, de forma a reforçar e intensificar o conteúdo da pornografia (RIBEIRO, 2016, p. 28).

Assim, as feministas que se posicionaram contra a pornografia o fizeram por entenderem que os vídeos são produzidos em um cenário de exploração e comercialização dos corpos dos atores envolvidos, retratando relações sexuais entre homens e mulheres de forma violenta e expondo as mulheres em geral de maneira pejorativa. Portanto, esse posicionamento não pode ser compreendido como similar à ideologia conservadora e moralista contrária à liberdade sexual, mas sim como uma crítica à violência (GRATON, 2019). "Para o movimento feminista anti-pornografia, em geral, não há problemas em se falar, representar ou fazer sexo; o problema reside quando a exibição das imagens pornográficas gera violência de gênero e perpetua a opressão de grupos minoritários" (RIBEIRO, 2016, p. 23).

A pornografia tornou-se intrínseca às sociedades ocidentais e influência em seus aspectos culturais (D’ABREU, 2013). Para Dines (2010), a pornografia está tão atrelada à cultura que está tornando-se sinônimo de sexo e, neste sentido, está "raptando" a sexualidade dos sujeitos, ditando a forma como as relações sexuais devem ser, a partir de um contato desumanizado, genérico e performático, não baseado em fantasias pessoais. Conforme entrevista da advogada Izabella Forzani, cedida à Revista Carta Capital (2021), apesar de a nudez e a sexualidade humana serem retratadas por séculos, a partir de 1970, com o filme "Garganta Profunda", houve uma grande alta na produção de filmes do gênero. Por algumas décadas a

RC: 105148

Disponível em: https://www.nucleodoconhecimento.com.br/psicologia/pornografia-eviolencia 
pornografia esteve sob o controle de grandes produtoras, no entanto, com o advento da internet houve uma importante mudança na forma de produzir e consumir conteúdos pornográficos. Se antes a pornografia costumava ser consumida em VHS, DVD e revistas como a Playboy, hoje a internet e os smartphones possibilitaram a popularização de sites específicos para esse material, garantindo a facilidade de acesso e o anonimato (GRATON, 2019).

Para compreender a dimensão da influência da Indústria Pornográfica na atualidade, deve-se considerar que ela é uma das mais lucrativas do mundo, sendo multibilionária. De acordo com o The Telegraph, em matéria publicada no ano de 2017, acredita-se que a pornografia online é um setor cujo faturamento anual é cerca de 15 bilhões de dólares por ano. A título de curiosidade, uma matéria do Quartz (2018) divulgou que a Netflix tem uma receita anual de 11,7 bilhões de dólares e Hollywood, 11,1 bilhões. De acordo com a mesma matéria veiculada pelo The Telegraph, o Pornhub-um dos sites mais relevantes do gênero pornográfico - revelou que seus vídeos foram assistidos 92 bilhões de vezes, por 64 milhões de visitantes diários, no ano de 2016. Segundo dados do próprio Pornhub, em 2018 o site recebeu mais de 33,5 bilhões de acessos. Entretanto, houve variações significativas no ano de 2020. De acordo com a plataforma, na primeira quinzena de março o número de pessoas que assistiram aos vídeos subiu $13 \%$ em relação a fevereiro. Ademais, a média diária de acessos no Brasil está aumentando e, até o início de julho de 2020, o uso apenas de sites de pornografia já havia aumentado quase $40 \%$, de acordo com matéria do Estado de Minas (2020).

Segundo a Revista Carta Capital (2021), em 2019 o Pornhub registrou mais de 6,8 milhões de novos vídeos. O Pornhub e a XVídeos, plataformas que lucram com este negócio, recebem cerca de três bilhões de visitantes mensais, estando entre os 10 sites mais acessados do mundo, conforme veiculado pela mesma revista, citando dados do site Visual Capitalist. Atrás apenas dos Estados Unidos, o Brasil é o segundo maior produtor de vídeos de pornografia do mundo (ROPELATO, 2013 apud D'ABREU, 2013) e, de acordo com o portal G1 (2018), referindo-se a um estudo divulgado pelo canal Sexy Hot, 22 milhões de pessoas assumem consumir pornografia RC: 105148

Disponível em: https://www.nucleodoconhecimento.com.br/psicologia/pornografia-eviolencia 
no Brasil - sendo que $58 \%$ dos consumidores são jovens de até 35 anos e $76 \%$ são homens. A partir dos dados expostos, que comprovam o crescente alcance e visibilidade da indústria pornográfica, diversas questões referentes ao impacto da pornografia estão sendo discutidas ao redor do mundo, como as possíveis interferências na educação sexual, o vício nos conteúdos pornográficos e a violência contra as mulheres e outros grupos minoritários.

A força que a indústria pornográfica alcançou e as proporções que tomou na cultura ocidental podem ser explicadas ao resgatar-se o conceito psicanalítico de "pulsão escópica". De acordo com Freud (1915), a pulsão tem a sua fonte numa excitação provinda do interior do próprio corpo, que provoca um estado de tensão, de desprazer. A meta da pulsão é a satisfação (que pode ser ativa ou passiva) e o objeto é aquele através do qual a pulsão poderá alcançar tal satisfação. Durante o narcisismo as pulsões têm satisfação autoerótica e, portanto, o prazer de olhar efetua-se no próprio corpo. A partir dele, desenvolve-se a pulsão ativa de olhar. Com o prazer do olhar "[...] a criança desenvolve uma atividade investigatória a partir de situações práticas da vida, passando então a elaborar uma série de teorias sexuais para explicar, por exemplo, como os bebês são feitos" (FREUD, 1905 apud BARROS; BARRETO, 2018, p. 309). A pulsão escópica, definida pelo prazer em ver, poderia explicar a curiosidade sexual, um dos fatores que pode ter contribuído para que a indústria pornográfica tomasse as proporções atuais (BARROS; BARRETO, 2018).

Objetivando traçar o porquê do surgimento e tamanha repercussão da indústria pornográfica, Wolf (1991) esclarece que as religiões patriarcais controlaram e destruíram a sexualidade feminina, sendo a clitoridectomia do Egito, o escudo e haste vaginal do Sudão e o cinto de castidade da Alemanha exemplos que ilustram esse processo. Assim, conforme avançavam a segunda onda do feminismo e a revolução sexual no início de 1970 - em que as mulheres conquistaram uma série de direitos, como acesso à educação superior, ao mundo dos negócios, além de quebrar antigos conceitos quanto ao seu papel social e proporcionar destaque à sexualidade feminina - houve uma reação que assumiu a função de coerção social sobre as mulheres, por 
exemplo, através das imagens de beleza feminina ideal a que foram expostas como nunca antes.

Nesse cenário, Wolf (1991) afirma que a pornografia invadiu em grandes proporções o contexto cultural, como uma contra investida à liberdade que as mulheres estavam alcançando, inclusive a liberdade sexual. Se com a chegada dos métodos anticoncepcionais, do aborto legalizado em países com grande influência e com o desmonte do padrão duplo de comportamento sexual, as mulheres poderiam contar com uma sexualidade mais livre, esta não demorou a ser comedida pelas coerções da "[...] pornografia da beleza e pelo sadomasoquismo, que surgiram para devolver a culpa, a vergonha e a dor à experiência feminina do sexo" (WOLF, 1991, p. 194). O surgimento da Playboy, em 1958, em contraponto à pílula anticoncepcional que passou a ser vendida nos Estados Unidos, em 1960, exemplifica esse processo.

De acordo com Ribeiro (2016), à medida em que ocorria a revolução sexual, como um fenômeno da contracultura, a indústria pornográfica apropriou-se dessas reivindicações e a sexualidade passou a ser vista como produto de consumo. Para a autora, a indústria pornográfica seria uma nova forma de opressão sexual, em que as mulheres são expostas como objetos sexuais para o prazer masculino, com seus corpos à venda, em um cenário que seguia desconsiderando o prazer feminino. Ao invés de retratar o desejo feminino visando a satisfação das mulheres, "[...] vemos simulações com manequins vivas, forçadas a contorções e caretas, imobilizadas e em posições desconfortáveis sob holofotes, cenas ensaiadas que revelam pouco sobre a sexualidade feminina" (WOLF, 1991, p. 199), ou seja, a serviço das instituições masculinas.

No cinema da década de 1980, filmes que retratavam a violência sexual tornaram-se comuns, com a tomada de "primeira pessoa", em que o espectador se identifica com o assassino ou estuprador. As fantasias que atraíam os olhares dos homens e das mulheres eram as que representavam a guerra dos sexos, reproduzindo as desigualdades de poder, inclusive nas relações sexuais. O estilo sexual feminino de 1960, descrito como "alegre, sensual, brincalhão, sem violência ou vergonha, sem 
medo das consequências" (WOLF, 1991, p. 197), foi rechaçado pela cultura popular, redefinindo o sexo terno e íntimo como entediante. Wolf (1991) argumenta que permitir que o sexo seguisse da forma de outrora era dar margens para a destruição de instituições que já estavam abaladas com a movimentação feminista. Assim, inseremse duas ideias de pornografia na cultura feminina: a leve, que "apenas" objetifica o corpo da mulher, e a pesada, que violenta este corpo.

A pornografia parece ter surgido, então, como uma espécie de manutenção do status quo, ou seja, uma forma de manter o lugar de subordinação da mulher em meio a um cenário de fortes mudanças. Nesse contexto, Kehl (1996) descreve uma espécie de mal-estar contemporâneo que impacta ambos os sexos. O lugar da mulher no cenário social e sexual modificou-se, as diferenças entre os sexos foram borradas e as novas identificações das mulheres passaram a ser com atributos que, originalmente, eram considerados masculinos. No texto Mal-estar na Civilização, Freud (1930 apud KEHL, 1996) abordou o "narcisismo das pequenas diferenças", tentando explicar as grandes intolerâncias acentuadas quando a diferença é mínima. Para Kehl (1996), referindose à dinâmica entre homens e mulheres, os homens sentem-se mais prejudicados, não apenas porque elas colocam em xeque o seu poder, mas sim porque desafiam a masculinidade. Ou seja, há uma aproximação das mulheres sem, de fato, tornaremse homens, que outrora foram chamadas de "bruxas" e queimadas na fogueira. "A onda de imagens de violência sexual derivou sua força da raiva dos homens e da culpa das mulheres com o acesso destas ao poder" (WOLF, 1991, p. 201).

Assim, a violência contra a mulher vem sendo constantemente retratada de maneira erótica nos conteúdos pornográficos. Em uma pesquisa realizada analisando um compilado de 304 cenas de "conteúdos adulto", provenientes das listas de mais populares segundo a Adult Video News, constatou-se que $88,2 \%$ das cenas apresentavam agressão física, principalmente espancamento, engasgos durante 0 sexo oral no homem, tapas, puxões de cabelo e enforcamentos. Além disso, 48,7\% dos filmes analisados continham agressão verbal. Os perpetradores da agressão eram homens em $70 \%$ das cenas e as mulheres eram o alvo da agressão em $94 \%$ (BRIDGES et al., 2010 apud D'ABREU, 2013).

RC: 105148

Disponível em: https://www.nucleodoconhecimento.com.br/psicologia/pornografia-eviolencia 
Uma pesquisa realizada em território nacional deparou-se com resultados similares ao analisar filmes presentes na seção de "Mais Vistos" no Brasil, no PornHub, com cerca de 19 milhões de visualizações. A pesquisa propunha-se a verificar os vídeos pornográficos mainstream, sem deter-se a nenhuma categoria específica, totalizando 20 vídeos analisados. Averiguou-se que em $95 \%$ dos vídeos havia a presença de atos violentos: violência física $(68,4 \%)$, sexual $(57,9 \%)$ e psicológica $(10,5 \%)$. Entre os atos de violência física, observou-se cenas em que o homem batia no rosto da mulher, vagina ou bunda, segurava de modo agressivo, puxava o cabelo, apertava a garganta como se pretendesse enforcá-la e, por fim, colocava o pênis na garganta da mulher agressivamente, o que causava engasgamentos e falta de ar. Nos vídeos em que continham violência sexual, constatou-se a representação de ato sexual sem consentimento, coação à prática sexual, masturbação ao lado de uma mulher dormindo, entre outras violências. Nos atos de violência psicológica, observou-se a representação da coação ao ato sexual por meio de ameaças (GRATON, 2019).

De acordo com as pesquisas supracitadas, verificou-se que atos de violência contra a mulher cometidos por homens constituem mais a regra do que a exceção nos vídeos pornográficos. Ressalta-se que ambas as pesquisas analisaram os vídeos mainstream, não se atentando a gêneros específicos que, devido à categoria, propõem-se a retratar a violência, como vídeos do gênero BDSM - sigla que significa bondage, disciplina, dominação, submissão, sadismo e masoquismo. A exibição dos corpos para o prazer masculino não é privilégio do século $\mathrm{XXI}$, porém a internet proporcionou vasta quantidade de conteúdos pornográficos de fácil acesso e, consequentemente, a violência tornou-se mais frequente. Jensen, um diretor da indústria, em entrevista à Adult Vídeo News, relatou que os fãs estão buscando conteúdos cada vez mais extremos e, segundo ele, não é possível supor qual o futuro da pornografia, à medida que a brutalidade e degradação das mulheres intensificamse (JENSEN, 2004 apud GRATON, 2019).

A violação do consentimento representada nos filmes mostra-se igualmente relevante à finalidade de compreender as nuances da violência contra a mulher na pornografia, tendo em vista que retrataria a desconsideração, uma falha ética constitutiva do RC: 105148

Disponível em: https://www.nucleodoconhecimento.com.br/psicologia/pornografia-eviolencia 
homem. De acordo com Ribeiro (2016), a pornografia apresenta alguns scripts comuns que transmitem a ideia de autoridade masculina e subalternidade feminina. Dentre estes aspectos, o "não-quer-dizer-sim" (RIBEIRO, 2016, p. 89), em que a negativa das mulheres aparenta significar o contrário, construindo um cenário de erotização da violação do consentimento. Além disso, há frequentemente a retratação da "resistência simbólica", em que a mulher diz não, mas comporta-se como se quisesse, reforçando mitos de que a resistência feminina ao ato sexual pode ser abrandada com investidas masculinas e, por fim, resultar em prazer (D'ABREU, 2010). Para Dines (2010), as mulheres são representadas como sempre prontas para transar, sem importarem-se com o que o homem deseja fazer.

Outro ponto referente à subalternidade feminina e autoridade masculina, representando a desigualdade entre os gêneros, está na apresentação das personagens dos filmes. De acordo com estudo de Cowan et al. (1988 apud D'ABREU, 2010), em que 282 personagens de 45 filmes foram analisados, verificou-se que em $62 \%$ dos casos os homens eram profissionais ou homens de negócio, enquanto as mulheres, em $58 \%$ dos casos, eram assistentes, donas de casa ou secretárias. Além disso, as mulheres eram frequentemente infantilizadas em seus trajes, vozes e ausência de pelos, retratando adolescentes ingênuas. Para Dines (2010), a mulher costuma ser usada na pornografia com o objetivo de satisfazer o homem, em que o clímax da cena é a ejaculação masculina. A afirmação de Dines pôde ser corroborada no estudo de Cowan et al. (1988 apud D'ABREU, 2010), em que 97\% das cenas com relações heterossexuais centravam-se na ejaculação do homem sobre a mulher.

Em consonância com o estudo supracitado, Graton (2019) pôde coletar resultados semelhantes: $75 \%$ das mulheres dos vídeos analisados pela autora aparentavam ser menores de idade, entre 15 e 18 anos, sendo que, em $65 \%$ dos vídeos não foi possível verificar a idade do homem, pois a cena era do ponto de vista dele. Além disso, termos como "novinhas" e "teen" estão todos os anos presentes na lista dos mais buscados no PornHub, citando escolas, com as mulheres trajando acessórios e roupas infantilizadas e portando ursinhos de pelúcia, muitas vezes contracenando com um 
"professor", em histórias baseadas no fato da mulher ser inexperiente, entre outras cenas que retratam uma mulher frágil e indefesa frente ao homem (GRATON, 2019).

Marinho (2017) aponta que a formação do discurso da obra de um cineasta é resultado de uma realidade interior, que reúne discursos, saberes e vivências. Se a obra se estrutura a partir da subjetividade do artista, é possível indicar a supremacia do gênero nesse olhar, fruto de uma herança cultural patriarcal, que atribui papéis de gênero relativos à dominação. Ceccarelli (2011), refletindo sobre a forma como os homens e mulheres costumam ser retratados na pornografia, considera que a posição viril do homem em oposição à humilhação da mulher resulta da posição dela no imaginário cultural. Assim, explicita-se nas expressões artísticas, inclusive nos filmes pornográficos, como a sociedade, em geral, compreende a relação entre homens e mulheres.

A grande fascinação do ser humano pelo cinema pode ser devido à busca pelo prazer escopofílico, conforme anteriormente esclarecido. O encontro com a imagem possibilita uma impressão do real, capaz de produzir sensações, o que pode ser explicado pela possibilidade do espectador estar em frente a um espelho do seu mundo interno. "A exploração psicanalítica traz, muito claramente, o inconsciente do espectador como identificação com o cinema, como se o filme fosse um espelho dentro do imaginário psíquico" (MARINHO, 2017, p. 183), correlato à identificação primária, em que a criança distingue a si mesma no reflexo do outro. Para Marinho (2017), a partir do sistema patriarcal, o papel da mulher é construído de modo a refletir os desejos inconscientes masculinos. O espectador, então, projeta-se ao filme, identificando-se com o olhar do protagonista, tornando os dois olhares um só. Assim, existe o olhar da câmera, imbuído do viés masculino; o olhar do homem responsável pela narrativa, formado para buscar a figura da mulher como objeto para sua satisfação pelo olhar e, finalmente, o olhar do espectador masculino, que reproduz os dois olhares.

Mulvey (1991 apud MARINHO, 2017) considera que a objetificação da mulher feita pelo olhar masculino é uma reação à angústia de castração que ela provoca, 
despindo-a de seu caráter desafiador e atribuindo-a uma função submissa, sendo objeto de fetiche e servindo unicamente ao prazer masculino. Retomando Freud (1930), ao mesmo tempo que para poder conviver em sociedade o ser humano precisou recalcar algumas tendências destrutivas, para o narcisismo é difícil tolerar as diferenças que aproximam homens e mulheres cada vez mais, sendo que colocar a mulher num papel inferiorizado neutralizaria a ameaça produzida por ela. Assim, criase na pornografia uma narrativa opressora, pautada na violência, na objetificação e na desigualdade. A narrativa dos filmes reflete a subjetividade dos sujeitos, que foi formada nesse emaranhado cultural.

\subsection{PORNOGRAFIA E AS CONSEQUÊNCIAS PSICOLÓGICAS NAS MULHERES}

A violência contra a mulher presente na pornografia trata-se de um reflexo de subjetividades permeadas por discursos violentos, que atravessam a história e colocam a mulher em uma posição de subordinação no imaginário social. Na indústria pornográfica encontram-se inúmeros relatos de violências contra ambos os gêneros, como denúncias de vítimas de tráfico sexual, veiculação de vídeos de estupro e abuso infantil - que, inclusive, levou à exclusão de milhões de vídeos do PornHub, depois de uma reportagem do New York Times - um número de suicídio elevado devido às problemáticas enfrentadas por esses sujeitos, bem como o vício em drogas, o alto índice de contágio por doenças sexualmente transmissíveis, ferimentos nas regiões íntimas, entre outras vivências enfrentadas pelas atrizes e atores, conforme a Revista Carta Capital (2021). Os relatos de atrizes pornôs que sofreram com violências ou outros momentos traumáticos nos settings de filmagem e que, por isso, enfrentam impactos psicológicos, mostram-se um claro exemplo das problemáticas envolvidas no contexto da indústria pornográfica. No entanto, dado os objetivos do presente estudo, salientam-se os possíveis impactos dessa violência nas mulheres em geral.

Ribeiro (2016) considera que os conteúdos presentes na pornografia não apenas refletem a realidade, como possuem o poder de modificá-la e, por esse motivo, a pornografia poderia ser considerada uma forma de discurso de ódio contra as

RC: 105148

Disponível em: https://www.nucleodoconhecimento.com.br/psicologia/pornografia-eviolencia 
mulheres. Segundo a autora, a pornografia é uma prática discursiva, ou seja, um meio de expressar opiniões e sentimentos a respeito de determinados temas, e acaba por "[...] exteriorizar e/ou incitar a raiva, o ódio e a intolerância, de forma a instigar e/ou encorajar a violência, a humilhação a hostilização, a discriminação e, mais ainda, a opressão de um gênero pelo outro" (RIBEIRO, 2016, p. 119).

De acordo com Gomes (2021), o discurso de ódio possui motivações inconscientes e atravessa a história da humanidade como uma manifestação destrutiva que atrapalha a organização em sociedade. Em concordância com o proposto por Mulvey (1991 apud MARINHO, 2017), que afirma que a objetificação do corpo feminino feita pelo homem está a serviço de eliminar a angústia de castração, Gomes (2021) argumenta que o discurso de ódio está no âmbito de uma percepção paranoica e, no caso do discurso de ódio contra as mulheres, forma-se porque elas supostamente constituiriam uma "ameaça à superioridade do homem" (GOMES, 2021, p. 474, grifo do autor). Nesse contexto, o fortalecimento de uma indústria que propaga um discurso de ódio contra as mulheres no período em que elas buscavam romper com amarras que as mantinham em uma posição de inferioridade, demonstra uma espécie de silenciamento, opressão, uma tentativa de manter as engrenagens como estavam dispostas, neutralizando a ameaça representada pelas mulheres.

Objetivando compreender os possíveis impactos psicológicos que o discurso de ódio contra as mulheres promovido pela pornografia é capaz de causar, para além da forma de silenciamento e opressão que é inerente à formação da indústria pornográfica, é necessário resgatar o processo de constituição psíquica do sujeito. O filhote humano nasce completamente desamparado, dependendo inteiramente do Outro primordial para sobreviver. Aquele que cumpre a função materna, atentando-se às necessidades corporais da criança, irá interpretar, traduzir e atribuir significados aos estímulos internos aos quais o bebê apenas reage e não é capaz de discriminá-los (TEPERMAN, 1999). De acordo com Winnicott (1988), as mães preparam-se para a tarefa de cuidar de um bebê desenvolvendo a capacidade de identificação com ele e tornando-se parte de um ambiente suficientemente bom. O autor aponta que, inicialmente, é impossível 
descrever uma criança sem incluir os cuidados que ela recebe, tendo em vista a sua importância.

Em consonância com Winnicott, Teperman (1999) destaca que as mães, de forma espontânea e inconsciente, exercem a função de libidinizar e realizar a incorporação simbólica no bebê. Bleichmar (1994) denomina "narcisismo transvazante" o processo que transcreve os seres humanos em um sistema de signos que, futuramente, darão origem ao ego - como no exemplo de uma mãe que, ao atribuir uma consciência igual a sua ao seu filho, abre a possibilidade de que ele possa sentir-se humano. A função materna, portanto, cumpre majoritariamente a função de ligar a pulsão através dos cuidados investidos pelo adulto ao corpo infantil. Ainda que em um primeiro momento dependa inteiramente daquele que cumpre a função materna, o bebê responderá de forma singular aos cuidados dispensados pelo cuidador, fisgando o desejo dos pais e, assim, inaugurando o circuito pulsional, marcando o caminho do bebê que vai do registro da necessidade para o campo do desejo (TEPERMAN, 1999). Assim, o outro mostra-se imprescindível para a constituição de um sujeito, deixando marcas no psiquismo que dizem respeito ao cuidado, à proteção, e que a criança será capaz de identificar-se, tomando o seu corpo e sua intimidade como valorosos e dignos de serem cuidados e preservados.

Partindo-se do pressuposto psicanalítico de que o ser humano se constitui a partir do olhar do outro, o discurso de ódio exprime um olhar repleto de negatividade, constituindo narrativas violentas que

[...] são suficientes para criar condições de uma experiência traumática do sujeito-alvo, levando a autopercepções de inferioridade, impotência, inadequação e vulnerabilidade. Isso se potencializa pelo fato de que aquilo que é odiado é algo constitutivo do sujeito, sendo imutável e irremovível (nacionalidade, sexualidade, raça e outros) (GOMES, 2021, p. 476).

Referindo-se ao discurso de ódio, Gomes (2021) questiona:

Como dimensionar o sofrimento causado por um discurso que diz que o sujeito não é bem-vindo, que é diferente, que é inferior? Ou por leis e 
regras sociais que decretam que alguém deve ter menos direitos, ou até ser morto, por ser quem é? (GOMES, p. 476, grifo do autor).

Assim, detecta-se um importante aspecto destrutivo do discurso de ódio contra a mulher presente na pornografia mainstream - manifestado principalmente através da violência - na medida em que coloca um corpo que constitutivamente deveria ser um lugar da intimidade, do cuidado, em uma posição que legitima que ele possa ser violado, violentado, humilhado e que, intrinsicamente, devido à sua anatomia, possui menos valor, servindo única e exclusivamente para a satisfação masculina.

Gomes (2021) também ressalta a potencialidade traumática dos discursos de ódio nos sujeitos que são vitimados. Dentre os seus apontamentos, expõe que o traumático pode ser entendido como algo instalado como estranho ao sujeito, estrangeiro, causador de angústia; ademais, discorre que outra questão significativa referente ao trauma diz respeito ao entorno que promove a negação ou o não reconhecimento do caráter traumático do que é experienciado pelo sujeito, ou seja, quando questionada a legitimidade da experiência. A autora aponta que a negação, associada à incapacidade do sujeito nomear o conflito vivenciado, resulta em sofrimento psíquico devido a um excesso pulsional que não encontra vazão simbólica.

Considerando que a violência contra a mulher costumeiramente é naturalizada na sociedade, tendo em vista que alicerça suas bases nas relações patriarcais, o sofrimento causado por tal violência é relativizado pela pornografia. Conforme anteriormente esclarecido, a pornografia mainstream propõe-se a retratar a violência contra a mulher como elemento colaborador para a excitação sexual, e não como algo reprovável, como aconteceria com a manifestação de uma violência de um grupo por outro em quaisquer outras formas de produções audiovisuais ou discursos. Assim, para além da pornografia constituir um discurso de ódio em si mesma, torna-se possível associá-la ao impacto da deslegitimação da experiência de violência que muitas mulheres são submetidas.

Outrossim, Ribeiro (2016) destaca a manutenção de determinados estereótipos de gênero perpetuados pela pornografia, inclusive padronizando a forma como os 
sujeitos devem vivenciar a própria sexualidade. Para a autora, este fato torna-se um agravante, considerando que pessoas cada vez mais jovens utilizam a pornografia como meio de educação sexual e, portanto, podem ser afetadas e influenciadas por suas narrativas. A pornografia deixou de ser um material restrito a um seleto grupo de homens com o advento da internet, tornando-se cada vez mais parte da cultura ocidental, sendo consumida, inclusive, entre os mais jovens. Conforme uma matéria do El País (2019), o início do consumo de conteúdos adultos, entre os meninos, é entre 9 e 10 anos de idade. Levando esse dado em consideração, é preciso destacar que, apesar de que o instinto para a prática sexual seja algo inerente aos seres humanos, grande parte do comportamento sexual é aprendido, inclusive através de filmes que mostram uma relação sexual cada vez mais violenta. A pornografia, nesse contexto

[...] dita comportamentos sexuais, demonstra como as mulheres e como os homens devem se relacionar em um contexto sexual e também não sexual, externaliza posições sexuais e formas de agir durante a relação sexual. $\mathrm{O}$ discurso da pornografia é sempre o mesmo - dominação masculina, inferioridade feminina - e a sexualidade externalizada pela pornografia também (RIBEIRO, 2016, p. 87).

A pornografia mainstream, enquanto um discurso que costuma retratar a relação sexual entre homens e mulheres de forma violenta, exibindo as mulheres de maneira pejorativa e contribuindo para a manutenção de estereótipos de gênero prejudiciais, mostra ser uma perigosa forma de educação sexual entre os jovens, que acessam os conteúdos adultos cada vez mais cedo. Associado a esse fato, referindo-se a estudos realizadas com adultos, Wolf (1991) afirma que pesquisas demonstraram que o consumo de pornografia torna homens menos propensos a acreditarem em vítimas de estupro e que passam a banalizar mais a gravidade de violências sofridas por mulheres, dados que irão impactar diretamente a realidade dessa parcela da população. No entanto, a autora vai além e questiona se o mesmo aconteceria com as mulheres. Ao que indica, existem indícios que apontam que isso pode ocorrer:

Wendy Stock descobriu que a exposição a imagens de estupro aumentava o interesse sexual feminino pelo estupro e aumentava suas fantasias de estupro (muito embora não convencesse as mulheres de que elas gostassem de força

RC: 105148

Disponível em: https://www.nucleodoconhecimento.com.br/psicologia/pornografia-eviolencia 
no sexo). Carol Krafka concluiu que as participantes da pesquisa "sentiam menor indignação com a violência [contra as mulheres] quanto mais viam, e que classificavam o material como menos violento" quanto mais ele Ihes era exibido (WOLF, 1991, p. 207).

Se antes a pornografia restringia-se a uma experiência quase exclusivamente masculina, a partir de 1970 expandiu-se, acompanhando as manifestações feministas, assim como imagens de corpos femininos "ideais". Desse modo, as mulheres foram expostas como nunca à perfeição com a qual deveriam comparar-se, trazendo a ideia de que seria necessário ter um determinado corpo ou rosto para experienciar o prazer sexual feminino (WOLF, 1991), tornando-o, novamente, mais difícil de ser alcançado. Desse modo, a comparação torna-se motivo para potencial sofrimento entre homens e mulheres: a comparação com a beleza ideal, com uma performance sexual irreal e com expectativas errôneas a respeito do sexo, tornando esse um terreno fértil para experiências frustrantes e performáticas, em que não é possível experimentar uma relação advinda da espontaneidade.

O significante "mulher" frequentemente encontra-se no discurso associado a uma série de elementos que dizem respeito a um lugar de submissão em relação ao homem. Conforme Quinet (1951), ao nascer o sujeito precisa adequar-se a um contexto que está posto. Nesse cenário, a família é o primeiro contato com o social que 0 ser humano experimenta, responsável por passar diversos significantes simbólicos que irão enquadrar o sujeito na cultura. Assim, produzem-se as neuroses, tendo em vista que o sujeito precisa adequar-se às expectativas suas e dos outros e, para isso, renuncia a parte dos seus desejos, almejando a possibilidade de conviver em sociedade. Bleichmar (1994), referindo-se à fundação do inconsciente, considera que ele é um produto da cultura, formando-se a partir da relação com o semelhante.

Portanto, em antagonismo aos saberes essencialistas, que visavam naturalizar a posição da mulher na sociedade, a psicanálise compreende que há uma constituição subjetiva advinda do encontro com o outro, como ocorre com a feminilidade. De acordo com Kehl (1998), a feminilidade foi uma produção, a partir da posição masculina, que se intensificou nos séculos XVIII e XIX, mas que foi tão significativa 
que segue presente na subjetividade das mulheres contemporâneas, valorizando características como passividade, timidez, sedução, sujeição e subordinação ao desejo masculino (VIEIRA; MOREIRA, 2020). É nesse contexto que Freud detecta a histeria como mal-estar feminino do século XIX, advinda de um cenário de extrema repressão, em que a manifestação histérica era o único meio de expressão no centro de uma cultura envolta por padrões tão rígidos de feminilidade. Uma das figuras mais importantes para a constituição dessa forma de feminilidade foi Rousseau (KEHL, 1998). O autor, referindo-se à posição que homens e mulheres deveriam ocupar, disserta:

Um deve ser ativo e forte, o outro passivo e fraco: é necessário que um queira e possa, basta que o outro resista pouco. Estabelecido este princípio, seguese que a mulher é feita especialmente para agradar ao homem. Se o homem deve agradar-lhe por sua vez, é necessidade menos direta: seu mérito está na sua força; agrada, já pela simples razão de ser forte (ROUSSEAU, 1762 apud VIEIRA; MOREIRA, 2020).

É na cultura que os sujeitos encontram ideais de feminilidade que irão interagir com sua constituição subjetiva, sendo a travessia edípica primordial para que ocorram as identificações aos ideais associados a cada gênero, que, de modo imaginário, garantem o pertencimento dos sujeitos ao subgrupo das mulheres ou dos homens (KEHL, 1998). O discurso da feminilidade, que segue servindo como referencial identificatório para as mulheres na atualidade, reforça suas bases na pornografia, na medida em que as produções expõem uma mulher submissa, passiva, fragilizada, dócil, infantilizada e sujeitada aos desejos masculinos, sendo objeto de fetiche e servindo exclusivamente ao prazer do outro.

Embora a grande indústria pornográfica tenha surgido apropriando-se de aspectos da revolução sexual, é notório que ela segue reproduzindo estereótipos, preconceitos e violências que aprisionam as mulheres há séculos. No que tange à feminilidade, Freud constatou, desde 1908, os seus impactos no sofrimento vivenciado pelas mulheres devido às restrições impostas por ela, que demandam uma repressão exacerbada da pulsão sexual. Freud (1908 apud VIEIRA; MOREIRA, 2020) expôs a existência de uma dupla moral sexual que, ao passo que concedia maior liberdade sexual aos 
homens, oprimia as mulheres para que mantivessem uma conduta sexual condizente com a moral da época, o que fazia com que elas sucumbissem a graves neuroses. Portanto, se a feminilidade surgia mostrando uma mulher submissa ao marido, ao lar e à maternidade, a pornografia vem para ratificar essa ideologia, na medida em que mostra uma mulher submissa e passiva, também, no sexo, sem que possa experienciar sua sexualidade de maneira mais livre e igualitária.

As mulheres, enquanto rompiam com a sentença de serem submissas e "inferiores", colocando-se cada vez mais como semelhantes ao homem, e protagonizavam uma revolução que possibilitaria maior liberdade sexual, viram surgir uma série de mecanismos que operavam de forma a mantê-las na sua posição de outrora, dentre eles a indústria pornográfica. A indústria pornográfica alimenta-se da culpa das mulheres por não mais corresponderem às expectativas impostas pela cultura, como também da ameaça que sua mobilidade representa aos homens, criando roteiros que parecem "puni-las" pela sua audácia de romperem com a opressão vigente. Assim, a narrativa da dominação masculina segue sendo retroalimentada, na medida em que os sujeitos recebem percepções que reduzem as mulheres a lugares de submetimento e, após, irão disseminá-las, inclusive através da pornografia, que acabam por impactar diretamente as mulheres. Conforme Saffioti (2004), o patriarcado é adaptável, e segue atualizando suas formas de dominação.

\section{CONSIDERAÇÕES FINAIS}

A história das mulheres é atravessada por violências. Diversos eventos sociais buscaram submetê-las ao controle, como através da caça às bruxas, com a transformação da sua sexualidade e capacidade reprodutiva em produtos de troca e por meio da função do estupro, que servia para dominar e reprimir as mulheres em diversos contextos. As relações patriarcais constituem o cerne da violência do homem contra a mulher e ocorrem a partir do poder exercido pela parte dominante sobre a parte dominada. No entanto, não são as diferenças inatas entre homens e mulheres que propiciam esse cenário, mas sim lugares construídos que seguem sendo 
validados através de instituições que tornam as desigualdades legítimas, como as leis, os mitos, a família e áreas do saber.

Nesse contexto, a divisão entre os sexos está tão enraizada na história que se coloca como natural e inevitável, e não como uma construção social. Para compreender de que forma a dominação masculina é naturalizada, tornando legítima a violência contra a mulher, resgatou-se que a constituição dos sujeitos ocorre a partir do encontro com o outro. Inicialmente, com o processo denominado de narcisismo primário, o Eu constitui-se através da imagem do outro, em que é necessário um investimento narcísico do adulto que torna possíveis as ligações responsáveis por sua origem. Posteriormente, o estado de narcisismo do sujeito é abandonado devido à identificação com figuras parentais e, mais tarde, com outras pessoas que adentram a vida do sujeito.

Conforme o estado de narcisismo é superado, o Eu passa a submeter-se às exigências sociais, inaugurando o Ideal do Eu. Em um cenário em que é culturalmente disseminada uma visão de menosprezo às mulheres, os sujeitos irão identificar-se com esse lugar e, caso tentem romper com essa percepção, há a culpa por não ter sido o que era esperado socialmente e internamente. Desse modo, a violência contra a mulher é legitimada pois é transmitida através das gerações de modo invisível e sem questionamentos, tendo em vista que os lugares que homens e mulheres ocupam já estão demarcados quando a criança nasce, diferenciando-os quanto ao gênero, em uma espécie de hierarquia que consente que há "dominantes" e "dominados". A forma que homens e mulheres assumem dentro da cultura, portanto, não é devido a algum destino inato, mas sim refere-se às relações sociais que, nesse caso, constituem uma dinâmica de desigualdade.

Surgida em um panorama em que as mulheres buscavam desvencilhar-se de amarras antigas relativas ao seu papel de gênero e opressão sexual, a pornografia tornou-se uma das indústrias mais lucrativas da atualidade. Devido ao seu amplo alcance, é possível considerá-la parte importante da cultura ocidental, constituindo um meio para propagar percepções referentes à posição que homens e mulheres ocupam no 
imaginário social. A representação da violência contra a mulher, conforme o presente estudo demonstrou, constitui mais a regra do que a exceção na pornografia mainstream, sendo constantemente retratada de maneira erótica nos conteúdos pornográficos, em um cenário em que as mulheres são expostas como objetos sexuais que visam unicamente a satisfação do prazer masculino. Assim, a violência contra a mulher é expressa através da representação de agressões físicas, verbais, sexuais e psicológicas, aos moldes das violências enfrentadas por grande parcela das mulheres no contexto diário, conforme pôde ser esclarecido através da Lei Maria da Penha.

A desigualdade entre homens e mulheres e a dominação masculina é também representada por meio de scripts recorrentes da pornografia mainstream. Nesses roteiros, a negativa das mulheres aparenta significar o contrário, arquitetando cenas que erotizam a violação do consentimento. Outrossim, frequentemente há a retratação da "resistência simbólica", em que apesar da mulher dizer não, comporta-se como se quisesse o que está sendo proposto, o que corrobora com mitos de que a palavra da mulher pode ser contornada por meio da insistência masculina. Ademais, seguidamente as mulheres são representadas como sempre prontas para o sexo, independentemente de quais sejam as vontades masculinas, retratando uma perspectiva misógina de que mulheres gostam de ser violentadas e de que a sua palavra e desejo não têm o mesmo valor que a palavra e o desejo masculino.

A posição subordinada da mulher aparece em outros aspectos referentes ao roteiro da pornografia mainstream. Primeiramente, destaca-se que na maioria das vezes os homens são retratados ocupando uma posição considerada socialmente "superior" àquela ocupada pelas mulheres. Entretanto, o que mais destaca-se com relação à submissão feminina é a retratação das mulheres como figuras infantis em seus trajes, vozes e aparência corporal, erotizando um cenário baseado no fato da mulher parecer frágil e inexperiente frente ao homem que irá dominar a relação sexual. Para além da representação nas telas, os termos "teen" e "novinhas" estão todos os anos presentes nas listas de mais buscados, o que indica que há uma forte identificação do público com o tema. Além da erotização da posição subordinada da mulher, abre-se RC: 105148

Disponível em: https://www.nucleodoconhecimento.com.br/psicologia/pornografia-eviolencia 
precedentes para uma discussão a respeito de uma aparente representação problemática da pedofilia nos roteiros pornográficos.

A submissão feminina também pôde ser identificada no fato de as relações sexuais, por via de regra, centrarem-se na ejaculação masculina, em que o prazer feminino costumeiramente é visto com menor relevância. Além disso, o fato de grande parte das cenas serem do ponto de vista do homem - em que sequer é possível identificar a sua idade - mostra quem é o público-alvo, ou seja, a quem destina-se esse material. De fato, o surgimento de uma indústria multibilionária que se apropriou de importantes temas - como a revolução sexual, depois de séculos de opressão das mulheres deturpando-os, com a finalidade de lucrar e funcionar para manter mecanismos de controle, apresenta-se de forma violenta, como um silenciamento e mais uma opressão sobre a sexualidade feminina. Novamente, destaca-se que tais violências, exibidas na pornografia de forma erótica, são motivos de sofrimento para muitas mulheres no mundo, vivências que atravessam a história da humanidade.

No tocante aos possíveis impactos psicológicos nas mulheres em decorrência da violência representada na pornografia mainstream, primeiramente salienta-se que ela pode ser compreendida como apenas mais um reflexo de uma cultura que já é altamente desigual e violenta no que tange às relações de gênero, mas também é possível considerá-la um discurso capaz de interagir com a realidade e modificá-la, configurando um "discurso de ódio" que promove o silenciamento. Considerando a importância do outro na constituição do sujeito, se o olhar do semelhante é apreendido como repleto de negatividade, pode levar a autopercepções de inferioridade e vulnerabilidade. Ademais, a experiência traumática do discurso de ódio pode ser potencializada com a naturalização da violência contra a mulher promovida pela sociedade e corroborada pela pornografia, que deslegitima o sofrimento gerado, erotiza as diversas violências e, frequentemente, atribui o sofrimento unicamente ao alvo, desconsiderando o entorno social.

Outrossim, considerando a indústria pornográfica como um produto cultural, apta a interagir e modificar o meio, é possível discutir as identificações que ela é capaz de 
despertar na audiência, principalmente nas mulheres. Tendo em vista que há uma culpa feminina por estar alcançando posições cada vez mais simétricas aos homens, a identificação das mulheres com figuras submissas, que precisam "castrarem-se" para satisfação masculina, é viável. O que corrobora com essa perspectiva é o fato da violência na pornografia mainstream ser naturalizada e apreendida pela audiência - formada por jovens, em geral - como uma experiência de sexo cada vez mais possível. Ademais, a domesticação da sexualidade feminina mostra-se geradora de sofrimento desde as graves manifestações neuróticas, estudadas por Freud, e é corroborada pelo discurso pornográfico, mostrando mulheres submissas aos desejos masculinos. Além disso, a comparação com ideais de beleza, com performances sexuais irreais e com expectativas deturpadas a respeito do sexo, pode favorecer um potencial sofrimento e constituir experiências sexuais frustrantes para as mulheres.

As concepções misóginas relativas às mulheres, bem como a violência contra a mulher, são anteriores à pornografia. No entanto, ela funciona como um "amplificador", difundindo e reforçando ainda mais a violência contra a mulher, estereótipos de gênero prejudiciais, dentre outras concepções e mitos referentes ao lugar de subalternidade que a mulher ocupa em referência ao homem e que alicerçam tais violências. Embora muitos estudos estejam sendo realizados em diversas áreas do saber a respeito dos reflexos da pornografia, é preciso aprofundar cada vez mais as discussões referentes aos impactos psicológicos em homens e mulheres, tendo em vista a dificuldade enfrentada para a coleta de dados no tópico correspondente a essa temática.

\section{REFERÊNCIAS}

ALMEIDA, Tânia Mara Campos de. As raízes da violência na sociedade patriarcal. Sociedade e Estado, Brasília, v. 19, n. 1, p. 235-243, jun. 2004. Disponível em: <https://bit.ly/3qivVNS>. Acesso em: 22 jun. 2021.

BARROS, Paulo Esber; BARRETO, Robenilson Moura. Corpo negro e pornografia: a fantasia do negro pauzudo. Bagoas-Estudos gays: gêneros e sexualidades, [S. I.], 
v. $12, \quad$ n. $19, \quad$ p. $301-315,2018$. Disponível em: <https://periodicos.ufrn.br/bagoas/article/download/16361/10917>. Acesso em: 21 jun. 2021.

BEAUVOIR, Simone de. O segundo sexo: a experiência vivida (1949). Tradução de Sérgio Milliet. 5. ed. Rio de Janeiro: Nova Fronteira, 2019, v.2.

BEAUVOIR, Simone de. O segundo sexo: fatos e mitos (1949). Tradução de Sérgio Milliet. 5. ed. Rio de Janeiro: Nova Fronteira, 2019, v.1.

BENES, Ross. Porn could have a bigger economic influence in the US than netflix. Quartz, [S. I.], 20 jun. de 2018. Disponível em: <https://bit.ly/2SSTOPR>. Acesso em: 21 jun. 2021.

BLEICHMAR, Silvia. A fundação do inconsciente, destinos de pulsão, destinos do sujeito. Porto Alegre: Artmed, 1994.

BOURDIEU, Pierre. A dominação masculina (1998). Tradução de Maria Helena Kuhner. 16. ed. Rio de Janeiro: Bertrand Brasil, 2019.

BRASIL. Lei n. 11.340/2006. Presidência da República, 2006. Disponível em: <http://www.planalto.gov.br/ccivil_03/_ato2004-2006/2006/lei//11340.htm>. Acesso em: 23 jun. 2021.

BRASIL. Lei n. 13.104/2015. Presidência da República, 2015. Disponível em: <http://www.planalto.gov.br/ccivil_03/_ato2015-2018/2015/lei//13104.htm>. Acesso em: 23 jun. 2021.

CECCARELLI, Paulo Roberto. A pornografia e o ocidente. Revista (In) visível. Portugal, v. 1, p. 25-34, 2011. Disponível em: <https://bit.ly/3gQHxV6>. Acesso em: 23 jun. 2021. 
COLLERA, Virginia. Sim, seus filhos veem pornô (e é assim que isso os afeta). Jornal EI País, [S. I.], 16 fev. 2019. Disponível em: <https://bit.ly/3gSQf4k >. Acesso em: 21 jun. 2021.

CONVENÇÃO Interamericana para prevenir, punir e erradicar a violência contra a $\begin{array}{lllll}\text { mulher. } & 9 & \text { junho } & 1994 . & \text { Disponível }\end{array}$ $<$ http://www.cidh.org/basicos/portugues/m.belem.do.para.htm >. Acesso em: 21 jun. 2021.

D’ABREU, Lylla Cysne Frota. Pornografia, desigualdade de gênero e agressão sexual contra as mulheres. Psicologia e Sociedade. Belo Horizonte, v. 25, n. 3, p. 592-601, 2013. Disponível em: <https://bit.ly/3gQjF4i>. Acesso em: 21 jun. 2021.

DAVIS, Angela. Mulheres, raça e classe (1981).Tradução de Heci Regina Candiani. São Paulo: Boitempo, 2016.

DINES, Gail. Pornland: how porn has hijacked our sexuality. Boston: Beacon Press, 2010.

FEDERICI, Silvia. Calibã e a bruxa: mulheres, corpos e acumulação primitiva (2004). Tradução de Coletivo Sycorax. São Paulo: Elefante, 2017.

FREUD, Sigmund. Introdução ao narcisismo (1914). In: __. Introdução ao narcisismo, ensaios de metapsicologia e outros textos. Sigmund Freud, Obras Completas. Tradução de Paulo César de Souza. São Paulo: Companhia das Letras, 2010, v. 12, p. 13-50.

. O mal-estar na civilização (1930). In: O mal-estar na civilização, novas conferências introdutórias à psicanálise e outros textos. Sigmund Freud, Obras Completas. Tradução de Paulo César de Souza. São Paulo: Companhia das Letras, 2010, v. 18, p. 13-122. 
. Os instintos e seus destinos (1915). In: . Introdução ao narcisismo, ensaios de metapsicologia e outros textos. Sigmund Freud, Obras Completas. Tradução de Paulo César de Souza. São Paulo: Companhia das Letras, 2010, v. 12, p. 51-81.

. Psicologia das massas e análise do Eu (1921). In: Cultura, Sociedade, Religião: O mal-estar na Cultura e outros escritos. Obras Incompletas de Sigmund Freud. Tradução de Maria Rita Salzano Moraes. Belo Horizonte: Autêntica, 2020, p. 137-232.

GOMES, Mariana de Toledo Nascimento. O discurso de ódio na clínica psicanalítica. Revista Família, Ciclos de Vida e Saúde no Contexto Social, [S. I.], v. 9, n. 2, p. 472-480, 18 abr. de 2021. Disponível em: <https://bit.ly/3vOAW1U>. Acesso em: 22 jun. 2021.

GRATON, Isabela Alves. O DNA da Dominação Masculina: pornografia e violência contra as mulheres. 2019. Trabalho de conclusão de curso (Bacharelado em Comunicação Social) - Faculdade de Comunicação, Universidade de Brasília, Brasília, 2019. Disponível em: <https://bdm.unb.br/handle/10483/26514>. Acesso em: 21 jun. 2021.

HOOKS, Bell. Teoria feminista: da margem ao centro (1984). Tradução de Rainer Patriota. São Paulo: Perspectiva, 2019.

JUCÁ, Julyanne. Por dia cinco mulheres foram vítimas de feminicídio em 2020, aponta estudo. Jornal CNN Brasil, São Paulo, 4 mar. 2021. Disponível em: $<$ https://bit.ly/3j8LOA3>. Acesso em: 21 jun. 2021.

KEHL, Maria Rita. A mínima diferença: masculino e feminino na cultura. Rio de Janeiro: Imago, 1996.

Deslocamentos do feminino (1998). 2. ed. São Paulo: Boitempo, 2016.

RC: 105148

Disponível em: https://www.nucleodoconhecimento.com.br/psicologia/pornografia-eviolencia 
KELLY, Guy. The scary effects of pornography: how the 21st century's acute addiction is rewiring our brains. Telegraph, 11 set. de 2017. Disponível em: $<$ https://bit.ly/2SgEv38>. Acesso em: 21 jun. 2021.

LERNER, Gerda. A criação do patriarcado: história da opressão das mulheres pelos homens (1986). Tradução de Luiza Sellera. São Paulo: Cultrix, 2019.

MARINHO, Ana Clara Pietroski. A estrutura patriarcal do olhar: uma análise da objetificação do corpo da mulher na imagem. O Mosaico, [S. I.], n. 15, dez. 2017. Disponível em: <https://bit.ly/3vQy2cO>. Acesso em: 22 jun. 2021.

MISOGINIA. In: Michaelis, Dicionário Brasileiro da Língua Portuguesa. [S. I.], Melhoramentos, 2021. Disponível em: <https://bit.ly/3gJDslH>. Acesso em: 22 jun. 2021.

MODELLI, Laís. 1 em cada 3 mulheres no mundo sofre violência física ou sexual, e cenário deve piorar com a pandemia, diz OMS. Portal G1, [S. I.], 09 mar. 2021. Disponível em: <https://glo.bo/3wOEeU4>. Acesso em: 23 jun. 2021.

MOTERANI, Geisa Maria Batista; CARVALHO, Felipe Mio de. Misoginia: a violência contra a mulher numa visão histórica e psicanalítica. Avesso do avesso, Araçatuba, v. 14, n. 14, p. 167-178, nov. de 2016. Disponível em: <https://bit.ly/3d6av15>. Acesso em: 22 jun. 2021.

MURARO, Cauê. 22 milhões de brasileiros assumem consumir pornografia e 76\% são homens, diz pesquisa. Portal G1, [S. I.], 17 mai. de 2018. Disponível em: <https://glo.bo/3qgU5rZ>. Acesso em: 21 jun. 2021.

OHANA, Victor. O consumo de pornografia favorece a violência contra a mulher? Revista CartaCapital, [S. I.], 8 mar. 2021. Disponível em: <https://bit.ly/3vR8wUZ>. Acesso em: 21 jun. 2021. 
ONU BRASIL. Taxa de feminicídios no Brasil é a quinta maior do mundo; diretrizes nacionais buscam solução. 9 abr. 2016. Disponível em: <https://bit.ly/3vQ6eFl>. Acesso em: 23 jun. 2021.

PEDRO, Claudia Bragança; GUEDES, Olegna de Souza. As conquistas do movimento feminista como expressão do protagonismo social das mulheres. Anais do I Simpósio sobre Estudos de Gênero e Políticas Públicas. Universidade Estadual de Londrina, Londrina, v. 1, 24 e 25 jun. de 2010, p. 1-10. Disponível em: $<$ https://bit.ly/3wOx95P>. Acesso em: 22 jun. 2021.

PONTALIS, Jean-Baptiste; LAPLANCHE, Jean. Vocabulário da psicanálise (1982). 4. ed. São Paulo: Martins Fontes, 2001.

PORNOGRAFIA. In: Michaelis, Dicionário Brasileiro da Língua Portuguesa. [S. I.], Melhoramentos, 2021. Disponível em: <https://bit.ly/3j3l1Jd>. Acesso em: 21 jun. 2021.

QUINET, Antonio. Os outros em Lacan (1951). Rio de Janeiro: Zahar, 2012.

RIBEIRO, Raisa Duarte da Silva. Discurso de ódio, violência de gênero e pornografia: entre a liberdade de expressão e a igualdade. 2016. Dissertação (Mestrado em Direito Constitucional) - Programa de Pós-graduação em Direito Constitucional, Universidade Federal Fluminense, Niterói, 2016. Disponível em: $<$ https://bit.ly/3wNxF4g>. Acesso em: 21 jun. 2021.

RICCI, Larissa; PEREIRA, Maria Irenilda. Como a pornografia distorce o sexo e incita violência contra as mulheres. Jornal Estado de Minas, [S. I.], 20 nov. de 2020. Disponível em: <https://bit.ly/3gJxpNV>. Acesso em: 21 jun. 2021.

SAFFIOTI, Heleieth. Gênero, patriarcado e violência (2004). 2. ed. São Paulo: Expressão Popular: Fundação Perseu Abramo, 2015. 
SÃO PAULO (Estado). Ministério Público do Estado de São Paulo. História da lei Maria da Penha. Disponível em: <https://bit.ly/3gKR00m>. Acesso em: 23 jun. 2021.

SILVA, Carolina Rocha. Com quantos medos se constrói uma bruxa? Misoginia e demonização da mulher no Brasil Colonial. Campos - Revista de Antropologia, [S. I.], v. 19, n. 2, p. 31-48, dez. 2018. Disponível em: <https://bit.ly/3gNEZax>. Acesso em: 22 jun. 2021.

TEPERMAN, Daniela Waldman. Do desejo dos pais ao sujeito do desejo. Estilos da Clínica. [S. I.], v. 4, n. 7, p. 151-158, 1999. Disponível em: <https://bit.ly/2SZxeoF>. Acesso em: 21 jun. 2021.

VIEIRA, Milla Maria de Carvalho Dias; MOREIRA, Ana Cleide Guedes. Ideais culturais e o tornar-se mulher: a cultura na constituição da feminilidade. Trivium, Rio de Janeiro, v. 12, n.1, p. 14-28, jun. 2020. Disponível em: <https://bit.ly/3qgddXe>. Acesso em: 21 jun. 2021.

WINNICOTT, Donald Woods. Os bebês e suas mães (1988). Tradução de: Jefferson Luiz Camargo. São Paulo: Martins Fontes, 1996.

WOLF, Naomi. O mito da beleza: como as imagens da beleza são usadas contra as mulheres (1991). Tradução de Waldéa Barcellos. 13. ed. Rio de Janeiro: Rosa dos Tempos, 2020.

2018 Year in Review. Pornhub, 11 dez 2018. Disponível em: $<$ https://bit.ly/3quQWVO>. Acesso em: 19 jun. 2021.

Enviado: Junho, 2021.

Aprovado: Janeiro, 2022.

RC: 105148

Disponível em: https://www.nucleodoconhecimento.com.br/psicologia/pornografia-eviolencia 